\title{
Elements of Brazilian Portuguese intonation
}

\author{
HUBERT TRUCKENBRODT \\ FILOMENA SÂNDALO \\ MARIA BERNADETE ABAURRE
}

\begin{abstract}
Experimental results on Brazilian Portuguese (BP) intonation are reported, concentrating on speakers from the Campinas area. A combined production and perception study shows that four nuclear contours are produced and distinguished: statements $\left(H+L^{*} L \%\right)$, emphatic statements (same, with higher FO), yes/no-questions ( $\left.L+H^{*} L \%\right)$, and surprise questions $\left(L^{*}+H L \%\right)$. A first semi-compositional analysis of the contours is offered, in which the declarative/interrogative distinction (not marked morphosyntactically on $B P$ yes/no-questions) is encoded by the choice of $L^{*}$ vs. $H^{*}$ pitch accent. A distinction corresponding to English committing vs. non-committing intonation is marked in addition by the choice of bitonal $H+L v s . L+H$ pitch accent. Further, it is shown that focus is marked by four out of our six speakers by the absence of a pitch accent following an early narrow focus, as well as by increased relative length of the focused constituent.
\end{abstract}

\section{Introduction}

In this study, conducted in the Campinas area of Brazil, we present numerical results of production and perception studies on Brazilian Portuguese (BP) intonation that allow us to develop an analysis of core phenomena of BP intonation in the autosegmental-metrical approach (Pierrehumbert 1980, Ladd 1996, Gussenhoven 2004, with the analysis of intonational meaning following Pierrehumbert and Hirschberg 1990 and Bartels 1997).

In doing so, we can draw on a range of previous literature on BP intonation, most of which builds on other frameworks of intonational analysis. This literature includes first descriptions of contours used in statements and different interrogatives in Gebara (1976), and a suggested set of nuclear contours in Cagliari (1981, 1982) and Massini-Cagliari and Cagliari (2001); 
the contributions by Gebara and Cagliari are based on Halliday (e.g. Halliday 1967). We also found a French school analysis (e.g. Fógnagy 1981) by de Moraes (1998). There is, further, a first exploration in terms of the autosegmental-metrical approach by Tenani (2002), followed by studies of focus by Fernandes (2007) and Lucente and Barbosa (2008). We also compare our results to European Portuguese (EP) with reference to Cruz-Ferreira (1998) and Frota (2000, 2002, to appear).

The main section of this paper is section 1, where we report results of a combined production and perception study on five nuclear contours in BP. The short section 2 is concerned with intonation in lists. Our results on the effect of narrow focus on the intonation contour are presented in section 3 . The main results are summed up in section 4 .

\section{Nuclear contours of BP}

We took as our starting point the classification of primary intonation contours of BP in Cagliari $(1981,1982)$, which we reproduce in Figure 1. Cagliari (1981) offers an analysis on the basis of perception, and Cagliari (1982) offers an acoustic basis for the 1981 proposals. The columns pertain to tone, pattern, meaning, and example. In row 1, a falling pattern is drawn for statements on the example 'Yesterday it rained a lot.' In row 2, a rising pattern is drawn for questions on the example 'Is it raining?'. In row 3, a rising pattern is drawn for incomplete expressions, exemplified with 'She said:' (continued by 'be quiet'). In row 4, a contour for a surprise question is drawn with the example 'I don't know?!'. Row 5 with the example 'But I handed the paper over!?' shows a contour for emphatic assertions that is falling at the end like the normal assertion, but drawn with a peak and a preceding rise towards that peak. Row 6 shows the intonation of the cleft sentence 'It was her who told me.' 


\begin{tabular}{|c|c|c|c|}
\hline Tom & Padrão & Significado & Exemplo \\
\hline 1 & $-\cdots---$ & declaração, asserção & Ontem choveu muito. \\
\hline 2 & $-\cdots----$ & interrogação & Está chovendo? \\
\hline 3 & $-. .11-\cdots$ & incompleto & (fique quieto) \\
\hline 4 & $-\because-\|-\cdots$ & surpresa interrogativa & Eu não sei?! \\
\hline 5 & $---\|-$ & asserção enfática & Mas eu entreguei o trabalho!? \\
\hline 6 & $\ldots+\ldots$ & "certas" frases relativas & em me disse. \\
\hline
\end{tabular}

Figure 1. Classification of intonation contours in Cagliari (1981), reproduced from Massini-Cagliari and Cagliari (2001).

On the assumption that the contour in row 6 is related to focus (which we investigate separately, see section 3 ), we investigated the contours in rows 1-5 first.

Two general pieces of information on BP are relevant here. First, the intonation contours in rows $1-5$ are not (as one might think from English) regularly accompanied by any syntactic or morphological marking of these distinctions. In particular, the distinction between declaratives and yes/nointerrogatives, marked in English by inversion, is not regularly marked in the syntax or morphology in BP. It rests on the intonation. For example, 'Maria gosta de sorvete.' 'Mary likes ice-cream.' is a declarative, and 'Maria gosta de sorvete?' 'Does Mary like ice-cream?' is the corresponding yes/no-question. Thus, the distinction between row 1 and row 2 carries a strong functional load, namely the declarative/interrogative divide. We will argue below that a surprise question like 'Maria gosta de sorvete?!' is comparable to the English declarative question 'Mary likes ice-cream?'; cf. row 4 of Figure 1. Second, it may be useful to know at this point already that main stress in BP falls by default on the last word of the sentence (Gebara 1976). 
In the following we briefly sum up descriptions of these contours by other authors.

Row 1: A falling pattern in statements/neutral declaratives was described earlier by Gebara (1976) and later refined by de Moraes (1998:183): "the neutral declarative pattern in BP is characterized by a drop in fundamental frequency $(\mathrm{F} 0)$ at the end of the utterance (more precisely, on the final tonic) (...)." Compatible with this more detailed description, we find in Tenani (2002) the transcription $\mathrm{H} \mathrm{L}^{*} \mathrm{~L}_{\mathrm{i}}$ for cases that seem to be of this kind. This corresponds in EP to the statement contour $\mathrm{H}+\mathrm{L} * \mathrm{~L} \%$ (Frota, to appear; see also Frota 2000, 2002).

Row 2: While Gebara (1976) and Cagliari (see Figure 1) conceive of the yes/no-question as having a final rise, the description of de Moraes (1998) includes a rise to a peak on the stressed syllable and a following fall. De Moraes $(1984,1998)$ conducted perception experiments that suggest that the distinction between declarative and interrogative rests not on the tonal movement onto the stressed syllable (which would be falling in the declarative and rising in the interrogative) but on the height of the stressed syllable (relative to the range used in the utterance, as we understand it): A relatively low stressed syllable is perceived as declarative and a relatively high stressed syllable as interrogative.

According to Cruz-Ferreira (1998) and de Moraes (1998), this BP interrogative contour is strikingly different from the EP interrogative contour, which is low on the syllable with nuclear stress and rising thereafter. Frota (2002, to appear) motivates an analysis of (neutral) yes/no-questions in EP as $\mathrm{H}+\mathrm{L} * \mathrm{LH} \%$.

Row 3: de Moraes (1998) describes a low-rise that marks continuation, which seems broadly compatible with Cagliari's drawing in row 3. This would seem to correspond to transcriptions of non-final contours as $\mathrm{L}^{*} \mathrm{H}_{\mathrm{i}}$ in Tenani (2002).

Row 4: Gebara (1976) also distinguishes surprise questions from normal yes/no-questions. Like Cagliari, she sees both of them as rising. While Cagliari draws different contours for the yes/no-question and the surprise question, Gebara sees the distinction in a higher pitch range for surprise questions. EP also seems to have something approximately corresponding to a surprise question contour, which Cruz-Ferreira (1998:171) describes as "typically used with echo-questions or with questions requiring repetition of a previous utterance." (The parallel that we see here may become clearer in the discussion section 1.3.) She describes it as high-rising, i.e. high on the nuclear syllable and further rising afterwards.

On the whole, the tonal analysis of statements and perhaps of statements with continuation (rows 1 and 3 in Figure 1) seems to be relatively clear, there are different descriptions of yes/no-questions (row 2), and only preliminary information is available about surprise questions and about emphatic assertions (rows 4 and 5). 


\subsection{Methods}

\subsubsection{Stimuli}

We employed the three sentences in (1). They consist of subject and verb. They were constructed in an attempt to maximize sonorants among the consonants for best-possible F0-measurements. The forms with conditional morphology allow antepenultimate stress, so as to avoid crowding of nuclear and final edge tones at the end of the utterance. (Otherwise, BP words are typically stressed on the penultimate or final syllable.)

(1) a. Nós manauaras ulularíamos.

we Manauans scream-CONDITIONAL

'We people from Manaus would scream.'

b. Nós alunos leríamos.

we students read-CONDITIONAL

'We students would read it.'

c. Nós meninos oraríamos.

we boys pray-CONDITIONAL

'We boys would pray.'

Each of these sentences was elicited in five different contexts, as shown in (2)-(6) for sentence (1b). The similar contexts for sentences (1a,c) can be seen in the appendix, which shows all stimuli. The meaning of conditional morphology and the speech act distinctions we are testing are orthogonal to each other in the cases at hand.

(2) Statement

O que aconteceria se Chomsky escrevesse um outro livro?

'What would happen if Chomsky wrote another book?'

[experimenter]

Nós alunos leríamos.

[subject]

'We students would read it.'

(3) Statement with continuation

$\mathrm{O}$ que você acha que aconteceria se Chomsky escrevesse um outro livro?

'What do you think would happen if Chomsky wrote another book?' Nós alunos leríamos, mas talvez tivéssemos muita dificuldade. [s.] 'We students would read it, but maybe we would find it very difficult.' 
(4) Emphatic statement

Eu acho que vocês não leriam se Chomsky escrevesse um outro livro.

'I don't think you would read it if Chomsky wrote another book.'

Mas nós alunos leríamos!

'But we students would read it!'

(5) Yes/no-question

$\mathrm{O}$ que você acha que aconteceria se Chomsky escrevesse um outro livro?

Nós alunos leríamos?

'What do you think would happen if Chomsky wrote another book? Would we students read it?'

(6) Surprise question

Eu acho que vocês alunos leriam se Chomsky escrevesse um outro livro.

'I think you students would read it if Chomsky wrote another book.' Nós alunos leríamos!? De jeito nenhum.

'We students would read it!? No way.'

\subsubsection{Speakers and recordings}

Since the productions were to be used in a perception task (see below), we calculated the number of speakers and recordings needed on the basis of what a listener in the perception task could work through in one hour. The best solution seemed to be to employ six speakers, and only one recording of each speaker for each stimulus. This seemed to us to be better (more representative of the language) than having two recordings of each speaker per stimulus and limiting ourselves to three speakers.

The experiments were conducted at the University of Campinas. Six monolingual speakers (age above 20) who had grown up in the area of Campinas and were currently living there were recruited. Speakers 1 and 2 were involved in setting up the experiment, but the other speakers had no background in linguistics or intonation analysis. Speakers 1-5 are female, and speaker 6 is male.

Contexts and sentences were both presented in written form. Parts to be read by the experimenter and parts to be read by the subjects were marked differently (see (2)-(6) on the right). The 15 sentences were presented, together with 17 sentences from the two other experiments below, in pseudorandomized order, in print on paper. The recordings were preceded by instructions. After a practice phase, each subject read the total of 32 sentences once. A recording session lasted about 20 minutes. 


\subsubsection{Perceptual recognition}

Perceptual recognition of category and of individual tokens for category was tested with the help of 24 native listeners, none of whom overlapped with the set of speakers.

To this end, the recorded sentences were separated from the contexts in Praat and integrated into a PowerPoint set-up. Listeners could play a given token one or more times, and had to make a choice of which of five contexts it would fit most naturally. For sentence (1b), these would be the five contexts in (2)-(6). The context set-up was similar for the other sentences. To focus attention on the categories we are interested in (rather than on irrelevant details of the contexts), each of the five contexts was presented with a label similar to the labels used in (2)-(6), i.e. 'Statement,' 'Statement with continuation,' etc. This presentation was in BP, without English translation. For each token, the judgment was recorded in a table on a sheet of paper.

Each listener judged the recordings of all speakers, a total of 90 tokens (3 sentences times 5 conditions times 6 speakers). The judgments were structured in three blocks corresponding to the three sentences in (1). For example, in the second block, the listeners went through the 30 tokens of sentence (1b) and had to assign each token to one of the categories (2)-(6). In each such block, the recordings of the six speakers were pseudo-randomized across speakers and categories.

\subsubsection{Calculation of the significance threshold for correct recognition}

Relative to the totals, and relative to the number and distribution of categories, one can calculate a threshold of correct recognitions, so that a number of correct recognition above the threshold is less likely than .05 in a chance distribution. The thresholds in the evaluations below are calculated as follows: Take an ordered list of 24 elements consisting of the elements $\mathrm{C}$ (correct recognition) and $\mathrm{W}$ (wrong recognition). For a given number of $\mathrm{Cs}$, $|\mathrm{C}|$, and a given number of $\mathrm{Ws},|\mathrm{W}|$, the number of different permutations of $\mathrm{C}$ and $\mathrm{W}$ elements in the list is $24 ! /(|\mathrm{C}|$ ! * $|\mathrm{W}|$ !). The likelihood of one such permutation depends on the number of categories. For five categories (A-E), the likelihood of one such permutation is $[0.2$ to the $|\mathrm{C}|$ th $]$ times $[0.8$ to the $|\mathrm{W}| \mathrm{th}]$. With three $(\mathrm{A}-\mathrm{C})$ and two (D,E) categories, these numbers are adjusted accordingly. The likelihood of getting $|\mathrm{C}| \mathrm{Cs}$ and $|\mathrm{W}| \mathrm{Ws}$ is then the product of the number of permutations in which these can occur with the likelihood of each such permutation. The likelihood of at least $n$ correct recognitions is the sum of the probabilities of having $n$ Cs and having any number of Cs greater than $n$. 


\subsubsection{Acoustic processing of the particularly well recognized productions}

Tokens that were recognized particularly well in the perception task were processed acoustically in Praat. The sentences were labeled with the help of spectrograms for word boundaries and boundaries of the stressed syllables. Measurements were made of the low and high turning points (discounting microprosodic effects) as well as of a low final point of the sentence, if there is one.

\subsection{Results on nuclear contours}

\subsubsection{Recognition of categories}

Table 1 shows the results of the perception experiment for recognition of categories. Grey cells highlight 'correct' answers: those in which the context assigned by a listener was the one in which an utterance was originally read.

\begin{tabular}{l|l|l|l|l|l|l|}
\multicolumn{2}{c}{} & \multicolumn{7}{c|}{ perception: assigned to } \\
\cline { 3 - 9 } \multirow{3}{*}{$\begin{array}{l}\text { produced in } \\
\text { context }\end{array}$} & A & B & C & D & E \\
\cline { 2 - 9 } & A: statement & 316 & 76 & 37 & 3 & 0 \\
\cline { 2 - 9 } & B: st. with continuation & 126 & 251 & 50 & 4 & 1 \\
\cline { 2 - 9 } & C: emphatic statement & 117 & 106 & 204 & 2 & 3 \\
\cline { 2 - 9 } & D: yes/no-question & 0 & 4 & 2 & 378 & 48 \\
\hline & E: surprise question & 1 & 1 & 2 & 90 & 338 \\
\hline
\end{tabular}

Table 1. Assignments of tokens to categories by the listeners.

'Correct' assignments are highlighted in grey.

It can be seen that the 'correct' answers are above 200 for all five categories. Assuming a chance distribution in each row, the likelihood of getting 200 or more answers in a particular cell of a particular row is extremely small (about 10 to the minus 36th). The 'correct' recognition of each of the five categories is thus significant for all categories.

At the same time, the likelihood of getting 106 or more answers in a particular cell of a particular row is still as low as 0.012 , so that some of the wrongly categorized statements $(\mathrm{A}-\mathrm{C})$ are also wrongly categorized in a way that is still significant. This deviation from a chance distribution in a given row can be explained by the overall good recognition of statements (A-C) as opposed to questions $(\mathrm{D}, \mathrm{E})$. The numbers show that statements and questions were kept apart particularly well. The pooled values for statements and questions in Table 2 highlight this. 


\begin{tabular}{|l|l|l|}
\cline { 2 - 3 } \multicolumn{1}{c|}{} & A-C statements & D,E questions \\
\hline A-C statements & 1283 & 13 \\
\hline D,E questions & 10 & 854 \\
\hline
\end{tabular}

Table 2. Recognition of statements and of questions.

This can explain why even some of the 'wrongly categorized' cells of Table 1 have numbers that are significantly high relative to a chance distribution in their respective row: The deviation from the chance distribution is triggered by the asymmetry between statements and questions in their row. ${ }^{1}$

Idealizing somewhat, we may use the assumption that statements and questions are distinguished from each other $100 \%$ as a baseline for further calculations. Assuming the correct recognition of statements as statements, but a chance distribution among the three kinds of statements (A, B, C), the significance threshold of $p<0.05$ is reached with 161 or more attributions in a given cell for statements. In Table 1, then, the 'correct' recognitions of each of $\mathrm{A}, \mathrm{B}$, and $\mathrm{C}$ are still significant against this baseline. For the questions $\mathrm{D}$ and E: Assuming the correct recognition of questions as questions, but a chance distribution among the two kinds of questions (D, E) in each row, the significance threshold of $p<0.05$ is reached with 234 or more answers in a particular cell. Table 1 shows significant 'correct' recognition among the categories $\mathrm{D}$ and $\mathrm{E}$ in this regard.

On the whole, our evaluation establishes particularly good recognition of statements in contrast to questions, but also significant recognition of each of the five categories statement (A), statement with continuation (B), emphatic statement (C), yes/no-question (D) and surprise question (E). This shows that these five categories of Cagliari $(1981,1982)$ are spoken differently in a way that can be recognized in BP.

Post scriptum to the statistical evaluations: Our method of statistical evaluation assesses the height of a number in a cell of Table 1 relative to the null hypothesis that the numbers in its row are distributed by chance. The significance of a high number by this calculation may have different sources, including (orthogonal to our purpose) a general tendency across the table to assign tokens to a particular column. As mentioned in footnote 1, there is such a tendency in the table, namely the assignment to unmarked categories. Thus, category A (normal statements) is used somewhat more (560) than the other two statement categories B and C (438 and 295). Similarly, category D

\footnotetext{
${ }^{1}$ There is also what appears to be a markedness asymmetry in the data: Listeners seemed to assign tokens to the unmarked category 'normal statement' more often than to a marked statement category (with continuation or emphatic), and to the unmarked category 'yes/no-question' more often than to 'surprise question'. See the 'Post scriptum' at the end of this subsection 1.2.1.
} 
(yes/no-questions) is used more than category E (surprise questions) (477 vs. 390). It is clear from the numbers that this alone does not explain the high numbers of 'correct' recognitions, but it may be useful to estimate the strength of this effect. We do this by 'adjusting' the numbers favored in this fashion in Table 1 . The number of correct recognitions of category A, 316, adjusted for this effect within the statements, is 243 (i.e. 316 times $(560+438+296) /(3$ times 560)), still well above the 161 threshold for statements. The number of correct recognitions of category D, 378, adjusted for this effect within the questions, is 282 , still well above the threshold of 234 for questions.

\subsubsection{Recognition of the category of individual tokens}

We further employ the perception results to single out tokens of production that were recognized particularly well for study of their F0properties. Table 3 shows the number of correct recognitions for each token.

\begin{tabular}{|c|c|c|c|c|c|c|c|c|c|c|c|c|c|c|c|c|c|c|c|}
\hline rm & & & & & & & & & & & 11 & & & & nph & atic & sta & mem & ents \\
\hline 1 & 2 & 3 & 4 & 5 & 6 & & 1 & 2 & 3 & 4 & 5 & 6 & & 1 & 2 & 3 & 4 & 5 & 6 \\
\hline a. 23 & 22 & 17 & 21 & 21 & 16 & a. & 18 & 7 & 8 & 4 & 12 & 13 & a. & 21 & 11 & 6 & 3 & 19 & 1 \\
\hline b. 21 & 10 & 9 & 20 & 15 & 18 & b. & 22 & 24 & 16 & 13 & 9 & 13 & b. & 14 & 10 & 16 & 9 & 16 & 7 \\
\hline \begin{tabular}{l|l} 
c. & 19 \\
\end{tabular} & 18 & & 18 & 18 & 21 & c. & 24 & 22 & 17 & 7 & 14 & & c. & 17 & 5 & 7 & 18 & 21 & \\
\hline
\end{tabular}

yes/no-questions
\begin{tabular}{|l|l|l|l|l|l|l|l|l|l|l|l|l|l|}
\hline & 1 & 2 & 3 & 4 & 5 & 6 & & 1 & 2 & 3 & 4 & 5 & 6 \\
\hline a. & 22 & 14 & 21 & 21 & 21 & 15 & a. & 17 & 21 & 23 & 21 & 13 & 17 \\
\hline b. & 23 & 23 & 24 & 23 & 23 & 20 & b. & 23 & 18 & 22 & 24 & 12 & 17 \\
\hline c. & 24 & 20 & 21 & 24 & 23 & 16 & c. & 19 & 20 & 24 & 23 & 17 & 7 \\
\hline
\end{tabular}

Table 3: Number of correct recognitions out of 24 for each token, arranged by speakers (16) who produced the tokens and by sentence a.-c., corresponding to (1a.-c.) above. Tokens recognized well and particularly well are highlighted (see explanation in the text).

We call a token reasonably well recognized if its recognition is significant by the following calculation: Using a significance threshold of $0.05 / 90$ (with Bonferroni adjustment for a total of 90 tokens), and assuming as a null hypothesis that each token is assigned with equal likelihood to any of the five categories, correct recognition of a token by 13 or more of the 24 speakers is significant. The reasonably well recognized tokens in Table 3 are marked with (light or dark) grey.

We call a token particularly well recognized if its recognition is significant by the following calculation: Using again a significance threshold of $0.05 / 90$, this calculation takes for granted that statements are recognized as statements $(\mathrm{A}-\mathrm{C})$ and questions as questions $(\mathrm{D}, \mathrm{E})$. Within statements and 
within questions the null hypothesis is again equal distribution among the categories (A, B, C for statements, D, E for questions). On this calculation, correct recognition among the three statements reaches significance with 17 correct recognitions, and correct recognition among the two questions reaches significance with 21 correct recognitions. The particularly well recognized tokens are marked with dark grey in Table 3.

The overall bias towards categories A and D (see end of section 1.2.1.) is not 'filtered out' in these calculations. There may be some tokens in categories $\mathrm{A}$ and $\mathrm{D}$ that would not be singled out by different ways of calculating. We accept this in the context of our generally high and conservatively chosen thresholds. It does not seem to be unduly problematic for our purposes.

Our evaluation of the F0-contour of the productions concentrates on the particularly well recognized productions. As can be seen in Table 3, there are a good number of these for yes/no-questions and surprise questions. With the statements, on the other hand, intonational marking of continuation and emphasis was particularly well recognized only with smaller numbers of tokens.

\subsubsection{F0-characteristics of the particularly well recognized tokens}

The particularly well recognized tokens of the categories A, C, D, and E are plotted in Figure 2, pooled for the six speakers. (Category B is discussed and plotted separately later in this section.) The measurements of temporal points and F0-height of the individual tokens were normalized for the plots. The plots show the length of the verb (vertical black bars), with the stressed syllable delineated by two vertical grey bars. The three temporal intervals shown result from normalization of the measured length of these intervals, averaged across all plotted tokens. The temporal location for plotting each F0 turning point was determined in such a way that its relative temporal location in its interval is linearly preserved. F0-height is normalized relative to an assumed baseline for each speaker. The baseline is at the height of the final L values of all plotted tokens for that speaker. The values are then plotted as multiples of that baseline above the baseline (Pierrehumbert 1980). For example, for a baseline of $100 \mathrm{~Hz}$, a value of $130 \mathrm{~Hz}$ would be plotted as 0.3 .

There are no turning points close to the right edge of the word because of a final [s] in all our stimuli. This [s] is regularly quite long, probably due to final lengthening. 

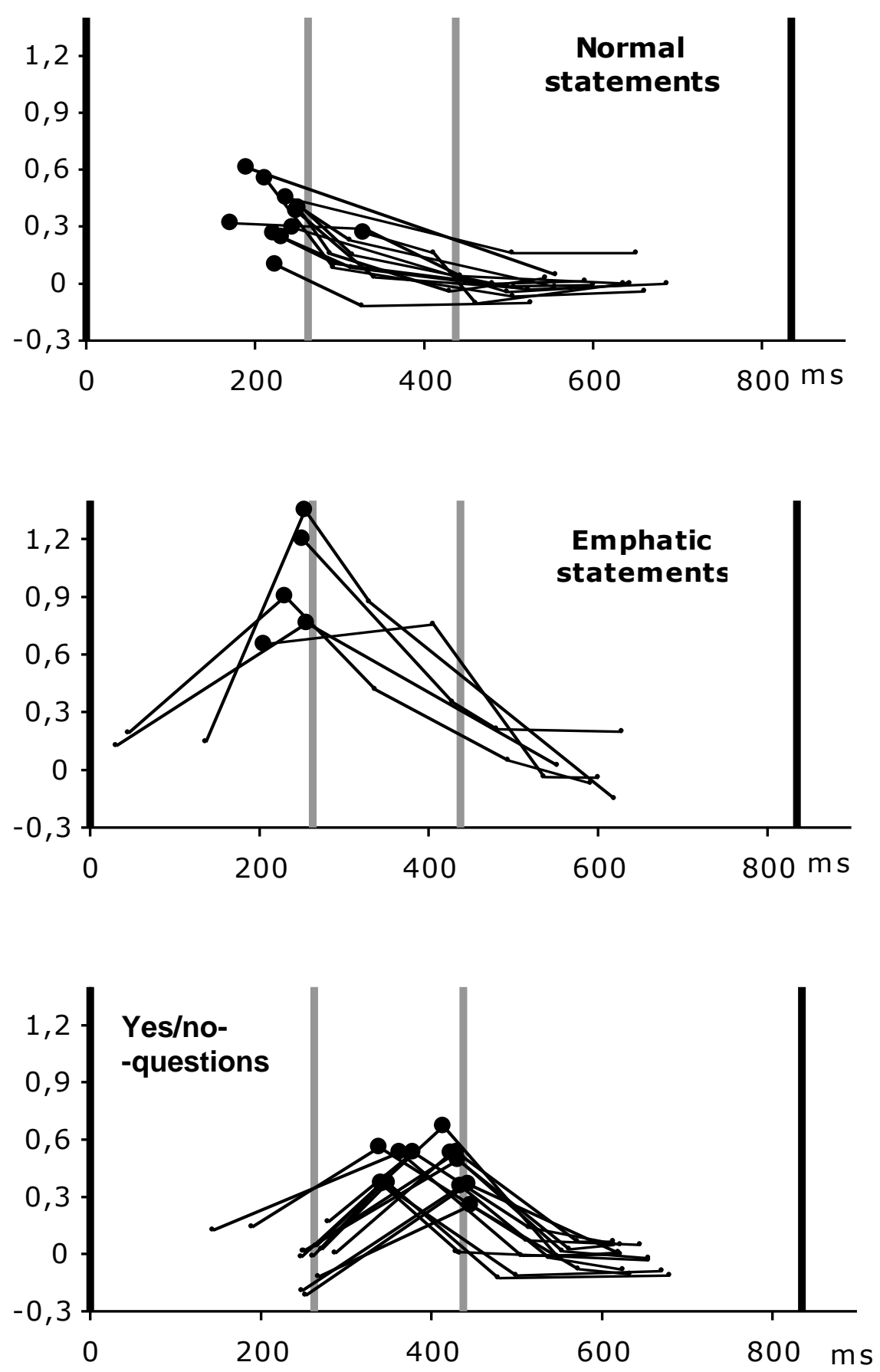


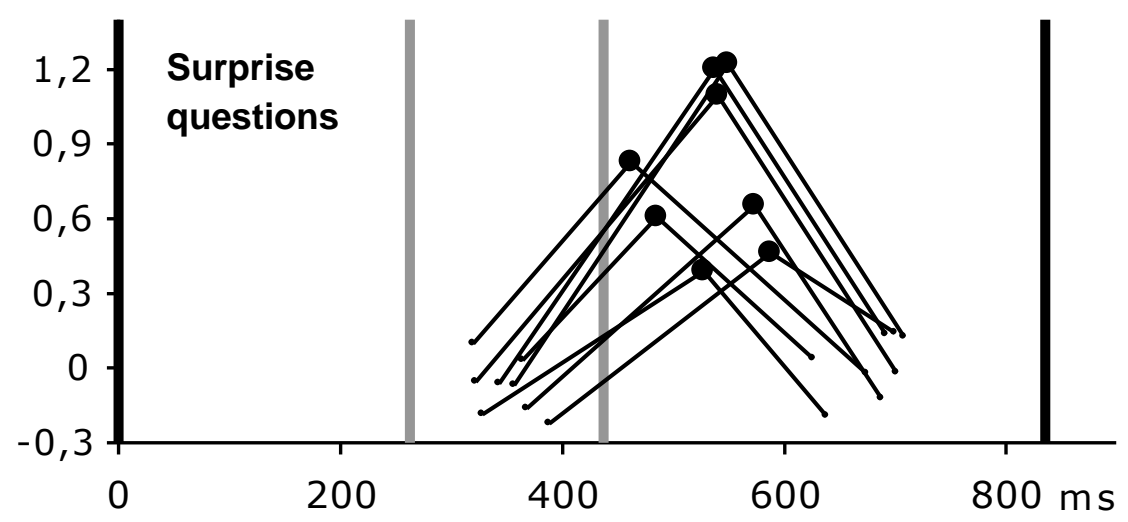

Figure 2. Plots of the tokens that were recognized particularly well in the perception experiments, for the categories A, C, D, and E. The vertical black bars represent the extent of the final verb. The vertical grey bars delimit the stressed syllable in the verb. The plots are normalized for F0 and for time (see explanation in the text) and pool the relevant productions of all six speakers.

The plots show the shared characteristics of each class, though individual tokens may show small deviations from these characteristics.

Normal statements: (a) A high turning point in the final word precedes the stressed syllable (large black dots). (b) In the stressed syllable a clear fall can be observed. (c) The steep fall often shows a low turning point in the stressed syllable; in these cases the turning point is followed by a more shallow fall ( $9 / 13$ cases). However, there are also cases with a more or less constant fall in the stressed syllable $(2 / 13)$ or with a fall that sets in late, in the stressed syllable, and with a low turning point following the stressed syllable (2/13). (d) The highest point is normally preceded by a high plateau-like course from the end of the last pre-nuclear rise (not shown in the plot).

Emphatic statements: (a) These share the high point before the stressed syllable and the following fall in the stressed syllable with normal statements. (b) This high point of the contour is scaled higher than in normal statements (typically above 0.6 in the emphatic statements, and typically below 0.6 in the normal statements). (c) In the five tokens, the low end of the fall follows the stressed syllable. (Three out of the five tokens show what may be a turning point in the stressed syllable, from a steeper to a slightly less steep fall, as can be seen in the plot.) (d) In three tokens, the high point preceding the stressed syllable is in turn preceded by a low turning point.

Yes/no-questions: (a) In clear contrast to the statements, these show a rise from around the beginning of the stressed syllable to a peak in the second part of the stressed syllable. (b) This is followed by a fall to a point after the 
stressed syllable. The temporal location and F0-height of the end of the fall is comparable to the low point in normal statements.

Surprise questions: (a) These show a final rise-fall as do yes/no-questions, and are thus also clearly different from statements. (b) The rise begins and ends significantly later than in yes/no-questions. Thus, while the L turning point of all particularly well recognized yes/no-questions is before the stressed syllable or less than $14 \%$ into the stressed syllable, the L turning point of all particularly well recognized surprise questions is at least as late as $33 \%$ into the stressed syllable (these later L turning points are all in the stressed syllable). The case is similar for the $\mathrm{H}$ turning points at the end of the two rises. In yes/no-questions, the high turning point of the particularly well recognized yes/no-questions occurs within the stressed syllable in 11/13 cases and only $0.02 \%$ into the post-stress interval in the remaining two cases. By contrast, the $\mathrm{H}$ turning point of the particularly well recognized surprise questions occurs later in all cases. In two cases only slightly later $(0.06 \%$ and $0.12 \%$ into the post-stress interval), and in the remaining $6 / 8$ cases noticeably later, at least $23 \%$ into the post-stress interval. (These alignment distinctions are significant because the values do not overlap.) (c) The peaks of the surprise questions are higher than those of the yes/no-questions. Our calculations compare these as fractions of the speaker-specific average of $\mathrm{L} \%$. In these terms, there is an overlapping range between 0.58 and 0.69 in which the peaks of two yes/no-questions and of three surprise questions are found; however, the remaining 11/13 yes/no-questions have lower peaks, and the remaining $5 / 8$ surprise questions have higher peaks. (d) In our recordings, the end of the final fall normally coincides with the end of voicing in the sentence.

Statements with continuation. No convincing consistent F0-characteristics can be isolated for statements with continuation (category B) in our recordings. Four of the six particularly well recognized tokens showed a rise, plotted in Figure 3. However, the other two particularly well recognized tokens, as well as the five other reasonably well recognized tokens, showed a fall before the boundary that is comparable to the fall in normal statements. 


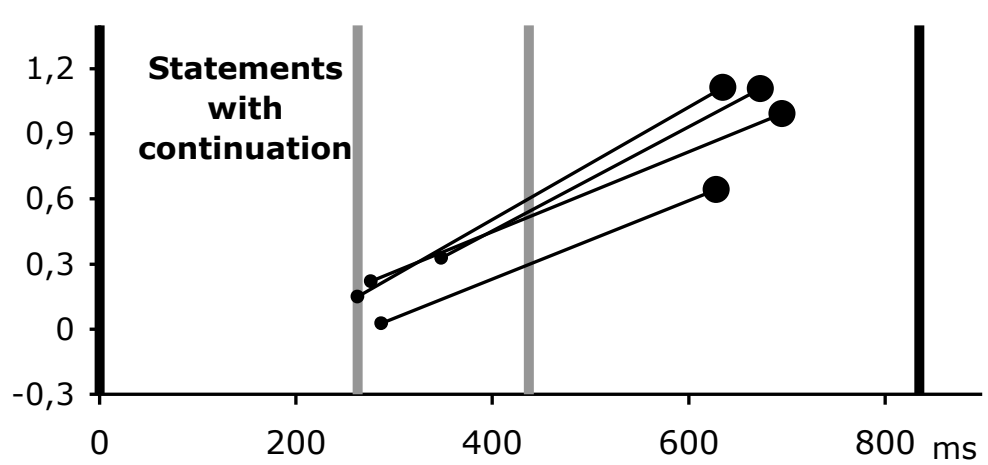

Figure 3. Statements with continuation: Here only the four tokens that show a rise are plotted. Plotting style and normalization are as in Figure 2.

Thus, we found relatively uniform F0-contours for the categories A, C, D, and $\mathrm{E}$, as described, but no uniformity in category B.

\subsection{Discussion of nuclear contours}

\subsubsection{Phonological analysis of the nuclear contours}

Statements were thus found to have a clear high turning point before the stressed syllable, and a clear fall on the stressed syllable, though the end of the fall may either be in or after the stressed syllable. These findings confirm and expand upon the description and drawings of a falling contour in BP declaratives by Gebara (1976) and Cagliari (1981, 1982) as well as the more precise description of de Moraes (1998) stating that the F0-drop sets in with the stressed syllable. We adopt the analysis of this contour from Tenani (2002) for BP and, for EP, from Frota $\left(2000,2002\right.$, to appear), and notate it as $\mathrm{H}+\mathrm{L}^{*} \mathrm{~L} \%$, following Frota (to appear). Given this analysis, we want to comment on the fact that there is not regularly a clear low turning point in the stressed syllable. One possible interpretation is that the $\mathrm{L}^{*}$ of $\mathrm{H}+\mathrm{L}^{*}$ can be executed late. Another possibility is that it can be executed incompletely, so that the phonetic point (or interval) that it defines is in many cases in the stressed syllable but higher than the following $\mathrm{L} \%$, and thus often occurs on the course of interpolation between the preceding $\mathrm{H}+$ and the final $\mathrm{L} \%$. This would be reminiscent of the phonetic implementation of $\mathrm{H}+\mathrm{L}^{*}$ in English (cf. Pierrehumbert 1980, Beckman and Pierrehumbert 1986), which, in other environments, puts $\mathrm{L}^{*}$ at a downstepped level relative to $\mathrm{H}$ but not at the level of other $\mathrm{L}$ tones. It would also be reminiscent of the phonetic implementation of sequences H L L (...) in Yoruba, with incomplete execution of the first $\mathrm{L}$ of the sequence, given one or more following L tones (Laniran 1992). The BP statement would thus have the same contour as the EP statement, $\mathrm{H}+\mathrm{L} * \mathrm{~L} \%$ (Frota 2000, 2002, to appear; see also 
Frota and Vigário 2000). We do not know whether comparable issues about the exact implementation of the $\mathrm{L}^{*}$ would arise in EP if sentences similar to ours were investigated.

Emphatic statements seem to contain the tonal contour $\mathrm{H}+\mathrm{L} * \mathrm{~L} \%$ of normal statements. It is possible that a preceding $\mathrm{L}$ tone $\left(\mathrm{L} \mathrm{H}+\mathrm{L}^{*} \mathrm{~L} \%\right)$ constitutes an optional part of this contour, as in three of our five particularly well recognized tokens.

A consistent distinction between emphatic statements and normal statements seems to be the higher scaling of emphatic statements. Pitch range has been claimed to be an indicator of the degree of speaker involvement (Bolinger 1986). Hirschberg and Ward (1992) experimentally confirmed this with a comparison of an uncertainty reading and an incredulity reading of the English $\mathrm{L}^{*}+\mathrm{H} \mathrm{L}-\mathrm{H} \%$ contour. Their perception experiment shows greater pitch range as a relevant parameter in the identification of incredulity, i.e. additional speaker involvement. It seems to us that the scaling difference between normal and emphatic statements in BP should be understood in terms of this correlation: The additional speaker involvement due to emphasis seems to be correlated with an upwards expansion of the pitch range in emphatic statements.

The overall falling shape, the additional height, and also the (apparently optional) low point preceding $\mathrm{H}+$ can be seen as confirming central aspects of the drawing of Cagliari $(1981,1982)$ for emphatic statements (see row 5 of Figure 1).

For yes/no-questions, our results are compatible with the description of de Moraes (1998) rather than the description of Gebara (1976) and Cagliari (1981, 1982): In our study, we find yes/no-questions not to be just rising; instead, the rise towards a peak in the stressed syllable is followed by a fall. We leave open whether this is due to the presence of two posttonic unstressed syllables in our material (i.e. Gebara and Cagliari might have observed a truncated version of what we found), or whether there are dialectal or other differences that account for the different observations.

We analyze yes/no-questions as having the contour $\mathrm{L}+\mathrm{H}^{*} \mathrm{~L} \%$. This seems to us straightforward, since the $\mathrm{L}+$ turning point typically occurs before the stressed syllable and the $\mathrm{H}^{*}$ peak typically occurs in the stressed syllable.

We analyze surprise questions as a phonologically different contour, $\mathrm{L}^{*}+\mathrm{H}$, due to the different alignment from yes/no-questions $\left(\mathrm{L}+\mathrm{H}^{*}\right)$. This different alignment is a new observation. We also confirm the additional height of surprise questions in Gebara (1976). We think that different alignment and greater height are two separate distinctions of surprise questions from yes/no-questions. Neither distinction can be analyzed as a secondary effect of the other. First, alignment cannot predict height: We are not aware of any reason to think that $+\mathrm{H}^{*}$ and $+\mathrm{H}$ in pitch accents have different height. (If anything, we would expect $+\mathrm{H}^{*}$ to have greater height than $+\mathrm{H}$, because $+\mathrm{H}^{*}$ is more directly tied to the prominent syllable; 
however, the height relations here are the other way around, with the $\mathrm{L}^{*+\mathrm{H}}$ of the surprise questions showing the greater height.) Second, greater height cannot predict later alignment: Greater height might in principle lead to a later $\mathrm{H}$ tone, all else being equal, since it takes more time to reach a greater height (if the angle is kept constant). Importantly, however, greater height of the peak cannot predict a later beginning of the rise, all else being equal. Thus, assuming temporal alignment targets for the beginning and end of a rise and a target for the steepness of the rise, we might expect that a higher rise starts earlier so as to stay close to the temporal targets of the end of the rise and to the target for the steepness. However, there is no reason to expect a higher rise to begin later. The systematic and exceptionless later start of the rise in the particularly well recognized surprise questions would remain unexplained. We therefore take the different alignment to be evidence of the different phonological pitch accents $\left(\mathrm{L}+\mathrm{H}^{*}\right.$ yes/no-questions, $\mathrm{L}^{*}+\mathrm{H}$ surprise questions). At the same time, we suggest viewing the greater peak height in a way that resembles the emphatic assertions: Additional speaker involvement (surprise or incredulity) in surprise questions may be correlated with an expanded pitch height in this category.

We cannot quite match the distinction we found with the distinction in the drawings of Cagliari $(1981,1982)$. However, we consider our analysis to be more broadly in line with his categorization insofar as we found that his fourth category, surprise questions, turns out to be a genuinely distinct intonational contour in BP.

A three-way distinction between statement contour, yes/no-question contour and surprise question contours, as described here for BP, seems to also exist in EP. According to Cruz-Ferreira (1998) yes/no-questions are lowrising in EP and echo/confirmation questions are high-rising in EP. As mentioned, Frota (2002, to appear) motivates an analysis of EP yes/no-questions as $\mathrm{H}+\mathrm{L} * \mathrm{LH} \%$.

Statements with continuation. The four tokens in Figure 3 would be analyzed as $\mathrm{L}^{*} \mathrm{H}$, in line with the transcription of contours in non-final environments in Tenani (2002).

As mentioned, we did not consistently elicit this contour in our experiment. An additional aspect of this problem is that the four tokens plotted in Figure 3 were all produced by speakers 1 and 2, the two speakers who were involved in carrying out the experiment. These speakers were of course not instructed to produce any particular contours, but they may have wanted to produce distinct categories for the benefit of the experiment. We do not see this as detrimental to the experiment as a whole. For one thing, the perception experiment, on which the results rest, is independent of a possible attempt to produce distinct contours for the benefit of the experiment. In addition, Table 3 shows for the other four categories that the number of particularly well recognized tokens of speakers 1 and 2 is always matched by a larger number of particularly well recognized tokens produced by the naive 
speakers 3-6. For the category of statements with continuation, however, this is not the case, and, as mentioned, the rising tokens in Figure 3 were only produced by speakers 1 and 2 .

De Moraes (1998:188) shows a systematic distinction between cases in which continuation after the end of a clause is marked by a rise and cases where it is not thus marked. In our choice of stimuli, we seem to have ended up on the wrong side of this divide.

The overall good recognition of statements with continuation in Table 1 may be due in part to the rising tokens, and/or to other cues (one possibility being less final lengthening on the verb in a position that is not utterancefinal).

Overall, then, our analysis supports the existence of three phonologically distinct categories in our BP materials: statements, yes/no-questions, and surprise questions. In addition, our results suggest that a correlation between speaker involvement and expanded pitch range, as has been claimed for English, is also found in BP. This would account for the perceptually relevant distinction between the emphatic and the non-emphatic statements, and it could account for the different peak height in yes/no-questions and surprise questions. $^{2}$

\subsubsection{Towards semi-compositional meanings in the $B P$ intonation system}

A closer analysis of the elements that make up the BP intonation contours is interesting for at least two reasons. First, as mentioned, BP does not set apart declaratives and yes/no-questions morphosyntactically (such as by inversion or by a morphological affix). The distinction rests entirely on the intonation. In English and many other languages, this is a distinction in syntactic sentence types. We thus want to know: What exactly codes this distinction in BP?

The second reason requires a longer introduction, but is no less interesting. In English, where interrogatives are marked by inversion in yes/no-questions, the intonation marks an additional distinction that may intuitively be thought

\footnotetext{
${ }^{2}$ With this, we may take another look at Table 3 and comment on some additional aspects of the variation there: The phonologically distinct categories (statements, yes/no-questions, and surprise questions) are each very well recognized overall: They show larger numbers of particularly well recognized tokens, and in each of these categories there are particularly well recognized tokens of speakers $1-4$, and with the exception of surprise questions also of speaker 5. (Speaker 6 did not seem to produce large numbers of particularly well recognized tokens across categories, with the exception of normal vs. emphatic statements.) The three phonologically distinct categories each also involve a large number of reasonably well recognized tokens. By contrast, the recognition of emphatic statements, while statistically significant, involved a smaller number of particularly well recognized tokens and of reasonably well recognized tokens. They were produced by a smaller number of speakers (three speakers for the particularly well recognized tokens). It is possible that the less striking recognition of emphatic statements is related to their not being a phonologically clearly distinct category.
} 
of as "statement vs. question intonation." We here call it committing vs. noncommitting intonation. The prototypical instance of committing intonation occurs in English in the $\mathrm{H}^{*} \mathrm{~L}$ - statement contour (a fall from a peak in the stressed syllable). In the complex inventory of English contours, Pierrehumbert and Hirschberg (1990) locate the element we call committing in the English $\mathrm{H}^{*}$ pitch accent, for which they postulate that the speaker seeks to add the relevant sentential content to the common ground of speaker and hearer. Bartels (1997) locates this instead in the English L- phrase accent, for which she discusses two meanings: speaker commitment and intended addition to the common ground. See also Truckenbrodt (to appear) for discussion.

Now, in English, the combination of syntactic marking of declaratives/ interrogatives and (non-)committing intonation allows for three sentence types of interest here: (i) declaratives with committing intonation are statements (e.g. It is raining.); (ii) yes/no-interrogatives with non-committing intonation (sometimes also with committing intonation) are questions (e.g. Is it raining?); (iii) crucially, declaratives with non-committing intonation constitute declarative questions, a different type of questions (e.g. It is raining?). The conditions on the use of declarative questions are discussed in detail in Gunlogson (2001). Gunlogson argues that the restrictions on the use of declarative questions stem from the combined contributions of the declarative sentence form and what we here call non-committing intonation. Interestingly, the BP surprise questions seem to be very similar in nature (if not identical) to declarative questions. According to Gunlogson, a crucial feature of declarative questions is that they require a context in which an expected 'yes'-answer (or, more precisely, a belief to this effect by the addressee) can be inferred. Thus, while yes/no-questions as in (7) can be used in contexts in which the answer is open, declarative questions cannot be used in these contexts, as shown in (8). There is no specific basis for expecting a 'yes'-answer.

(7) a. It's an open question. Did she lie to the grand jury?

b. What do you think? Should I cut my hair?

c. [guessing game] Is it bigger than a bread-box?

(8) a. \# It's an open question: She lied to the grand jury?

b. \# What do you think? I should cut my hair?

c. \# [guessing game] It's bigger than a breadbox?

Contexts in which declarative questions can be used are shown in (9). In these contexts an expected 'yes'-answer can be inferred. In (9a), a 'yes'-answer from A can be expected because it is equivalent to the preceding assertion by A. In (9b), a 'yes'-answer from A can be expected because A has presupposed as much in the use of 'the king of France.' In the intended understanding of 
(9c), a 'yes'-answer can be inferred (though not in a strict logical sense) in the common ground of A and B: A must have talked to Helena, otherwise she would not know about Mark and Helena's leaving for Japan. All examples are from Gunlogson (2001).

(9) a. A: There is a leopard in the living room.

$\mathrm{B}$ : There is a leopard in the living room?

b. A: The king of France is bald.

$\mathrm{B}$ : France is a monarchy?

c. A: Mark and Helena are leaving for Japan this week.

B: Oh ... you talked to Helena?

We find a similar distinction between BP yes/no-questions and surprise questions, though in BP, as was seen, the distinction is marked only by the intonation. Thus, yes/no-questions, but not surprise questions, are possible in the contexts in (10).

(10) Yes/no-questions but not surprise questions

a. É uma questão aberta: Ela mentiu ao júri?

'It's an open question: Did she lie to the grand jury?'

b. O que você acha? Devo cortar meu cabelo?

'What do you think? I should cut my hair?'

c. É maior que um laptop?

'[guessing game] Is it bigger than a laptop?'

On the other hand, surprise questions are possible in the contexts in (11), where an expectation for a 'yes'-answer can be inferred.

(11) Surprise questions possible

a. A: Tem um leopardo na sala de estar.

'There is a leopard in the living room.'

B: Tem um leopardo na sala de estar?

'There is a leopard in the living room?'

b. A: O rei da França é careca.

'The king of France is bald.'

B: A França é uma monarquia?

'France is a monarchy?'

c. A: Marcos e Helena estão indo ao Japão nesta semana.

'Mark and Helena are leaving for Japan this week.'

B: Ah, então você falou com Helena?!

'Oh, so you talked to Helena?'

The connection between Gunlogson's condition and the notion 'surprise' question would be that 'surprise' describes the circumstances under which one 
would ask such a question with an expected 'yes'-answer: Not seeking information in an open issue, they are instead reactions to utterances in which something unexpected comes up, which is then confirmed with the help of the declarative question.

Further exploration of this parallel is clearly required. Here we tentatively proceed on the assumption that the parallel is valid, and we explore what this may mean for the components of the BP nuclear contours we have found. The three crucial contours for statements $\left(\mathrm{H}+\mathrm{L}^{*} \mathrm{~L} \%\right)$, yes/no-questions $\left(\mathrm{L}+\mathrm{H}^{*}\right.$ $\mathrm{L} \%$ ) and surprise questions $\left(\mathrm{L}^{*}+\mathrm{H} \mathrm{L} \%\right)$ differ in their pitch accent in BP. They can be broken down into components for the dimensions discussed here as shown in (12). ${ }^{3}$

(12) Elements of the account of tonal contours in BP:
a. declaratives:
$\mathrm{L}^{*}$
b. interrogatives:
$\mathrm{H}^{*}$
c. non-committing intonation:
$\mathrm{L}+\mathrm{H}$
d. committing intonation:
$\mathrm{H}+\mathrm{L}$

(13) reviews how the crucial pitch accents of BP can be put together from these elements. The dimension of (non-)committing intonation determines either a rising $\mathrm{L}+\mathrm{H}$ or a falling $\mathrm{H}+\mathrm{L}$ pitch accent. The dimension declarative/interrogative determines where the star goes: to $\mathrm{L}$ in declaratives, and to $\mathrm{H}$ in interrogatives.

(13) statement $=$ declarative $\left(\mathrm{L}^{*}\right)$ with committing intonation $(\mathrm{H}+\mathrm{L})$ $=\mathrm{H}+\mathrm{L}^{*}$

yes/no-question $=$ interrogative $\left(\mathrm{H}^{*}\right)$ with non-committing int. $(\mathrm{L}+\mathrm{H})$ $=\mathrm{L}+\mathrm{H}^{*}$

surprise question $=$ declarative $\left(\mathrm{L}^{*}\right)$ with non-committing int. $(\mathrm{L}+\mathrm{H})$ $=\mathrm{L}^{*}+\mathrm{H}$

In this account, $(12 \mathrm{a}, \mathrm{b})$ integrates the findings of the perception experiments of de Moraes (1984, 1998): A relatively low stressed syllable is perceived as declarative and a relatively high stressed syllable is perceived as interrogative. The account in (12) would thus seem to be compatible with these important results.

\footnotetext{
${ }^{3}$ The assignment of meaning to the $\mathrm{L}+\mathrm{H}$ or $\mathrm{H}+\mathrm{L}$ component of a pitch accent, regardless of the position of the star, is also employed in the analysis of English in Pierrehumbert and Hirschberg (1990). There, English L+H pitch accents are postulated to invoke a scale, and English $\mathrm{H}+\mathrm{L}$ pitch accents are postulated to indicate that support can be inferred from the mutual beliefs. $\mathrm{H}^{*}$ pitch accents signal 'to be added to the mutual beliefs' and $\mathrm{L}^{*}$ signals the absence of this. The combinations $\mathrm{L}^{*}+\mathrm{H}, \mathrm{L}+\mathrm{H}^{*}, \mathrm{H}^{*}+\mathrm{L}$, and $\mathrm{H}+\mathrm{L}^{*}$ are semi-compositional in meaning. For example, $\mathrm{L}^{*}+\mathrm{H}$ signals the meanings of $\mathrm{L}^{*}$ and of $\mathrm{L}+\mathrm{H}$.
} 
Further, the analysis takes surprise questions $\left(\mathrm{L}^{*+\mathrm{H}}\right)$ as being declarative (containing $\mathrm{L}^{*}$ ), just as the English declarative question is declarative (does not employ inversion).

The non-committing intonation of the English declarative question is, in $\mathrm{BP}$, the $\mathrm{L}+\mathrm{H}$ rise (in surprise questions, then, $\mathrm{L}^{*+\mathrm{H}}$ ), shared by the $\mathrm{BP}$ yes/no-question. Inversely, we identify the $\mathrm{H}+\mathrm{L}$ fall with committing intonation: It adds the initial $\mathrm{H}$ tone to the declarative $\mathrm{L}^{*}$ in the $\mathrm{H}+\mathrm{L}^{*}$ statement contour.

Let us briefly look beyond these three core categories, beginning with the two additional categories of our experiment. $(12 \mathrm{a}, \mathrm{b})$ are compatible with the assignment of $\mathrm{L}^{*} \mathrm{H}$ - in 'statement with continuation' (see Figure 3, transcription in Tenani 2002), since the relevant examples are declarative in nature. (The alternative fall before continuation, $\mathrm{H}+\mathrm{L}^{*} \mathrm{~L} \%$, is of course likewise compatible with the identification of declaratives by L*.) Our fifth category, emphatic statements, is similarly compatible with the analysis in (12) and (13). As shown above, emphatic statements employ the statement contour $\mathrm{H}+\mathrm{L} * \mathrm{~L} \%$ with raised $\mathrm{F} 0$ and possibly a preceding $\mathrm{L}$ tone. For the purpose of the classification in (12)/(13), they are thus statements (declaratives with committing intonation), the desired result.

Our expectation for wh-questions (which we did not investigate) is tentative, but we briefly lay it out here. Wh-questions are interrogatives, which often show committing intonation in other languages (see Bartels 1997, Truckenbrodt to appear). In BP, we might thus expect interrogative $\mathrm{H}^{*}$ combined with committing $\mathrm{H}+\mathrm{L}$. To what extent this is borne out we cannot say. The short description of wh-questions in de Moraes (1998) includes a non-final equivalent to our $\mathrm{H}^{*}$ and a final fall. We suspect therefore that the best hope of having our prediction confirmed is, for this case, a separate realization of the two components $\mathrm{H}^{*}$ and $\mathrm{H}+\mathrm{L}$ (i.e. not merged into a single $\mathrm{H}^{*}+\mathrm{L}$, unlike what has been assumed for the other categories above). However, our expectation is tentative for several reasons. First, in some sense the interrogative feature is already morphosyntactically realized in the presence of the wh-word in this sentence type. Second, wh-questions are by no means limited to committing intonation in English (see Bartels 1997), and we expect similar variability in other languages.

In this section, we have laid out how the parts of the nuclear contours of BP can be assigned meanings in terms of the dimensions declarative vs. interrogative and committing vs. non-committing. It is interesting that a dimension encoded in the syntax in other languages (declarative/interrogative) seems to have a direct correlate in the intonation of BP, namely the distinction between $\mathrm{L}^{*}$ (declarative) and $\mathrm{H}^{*}$ (interrogative) pitch accent components. It was seen that this essentially implements important results of de Moraes (1998). Further, committing intonation (corresponding to English $\mathrm{H}^{*}$ and/or L-) seems to be encoded in the sequence $\mathrm{H}+\mathrm{L}$ and non-committing intonation in the sequence $\mathrm{L}+\mathrm{H}$ in BP pitch accents. 


\section{Intonation in lists}

We recorded the intonation of lists, so as to include a modicum of non-final intonation. Massini-Cagliari and Cagliari (2001) reproduce the table from Cagliari (1981) and amend it with different versions of declaratives, including the enumerations reproduced here in Figure 4. The drawing shows non-final rises and a final fall. We also wanted to see whether there is downstep among the members of the lists in these productions, as reported for a particular contour in English in Liberman and Pierrehumbert (1984), for Spanish in Prieto et al. (1996) and for German in Grabe (1998) and Truckenbrodt (2004, 2007).

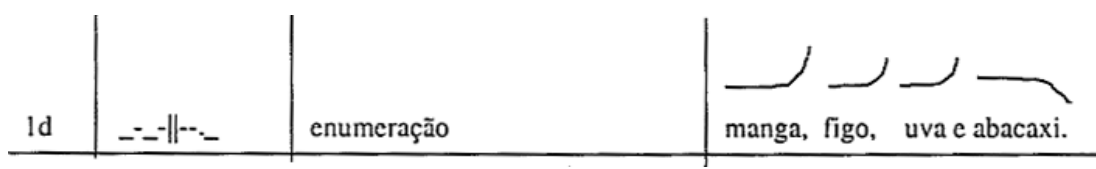

Figure 4. Enumerations. 'mango, fig, grape, and pineapple'. From Massini-Cagliari and Cagliari (2001).

\subsection{Methods}

The lists shown in (14) were elicited in the context of the question shown there, along with the recordings of the first experiment, and thus using the same six speakers. The lists are permuted so that each name occurs once in each position. The names were chosen based on their containing sonorant consonants, but also for the varying position of stress, Ângela being stressed on the first syllable, and Eleonor on the final syllable. The position of the stressed vowels is shown by underlining in (14).

(14) Quem você viu na festa? 'Who did you see at the party?'

a. A Manuela, o Manolo, a Laura, a Ângela e a Eleonor.

b. O Manolo, a Laura, a Ângela, a Eleonor e a Manuela.

c. A Laura, a Ângela, a Eleonor, a Manuela e o Manolo.

d. A Ângela, a Eleonor, a Manuela, o Manolo e a Laura.

e. A Eleonor, a Manuela, o Manolo, a Laura e a ÂAngela.

With one reading for each speaker, we thus have five list tokens from each of six speakers. The lists were labeled for phrases and for their stressed syllables with the help of spectrograms. The height of the turning points was measured. 


\subsection{Results}

Two typical renditions of lists are shown in Figure 5.
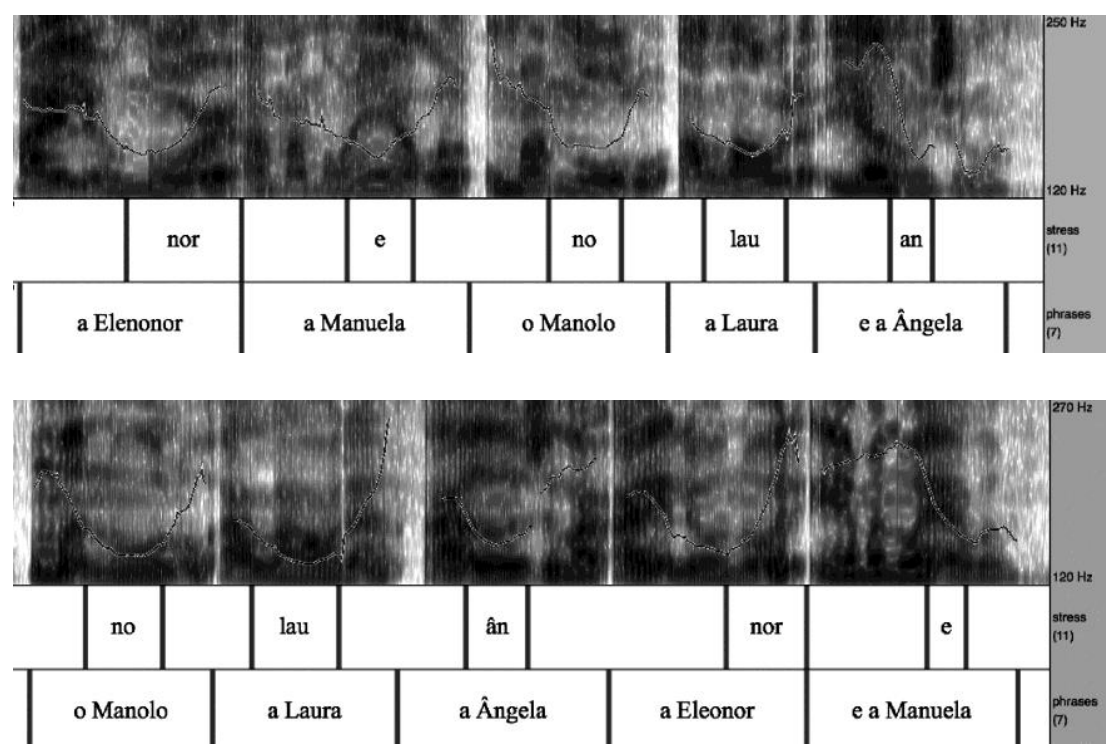

Figure 5. Renditions of lists by speaker 3 (above) and speaker 4 (below).

In non-final position, the tonal contours showed low turning points on the stressed syllables followed by a rise towards the end of the name. We analyze this as $\mathrm{L}^{*} \mathrm{H}$-. The analysis in terms of $\mathrm{L}^{*}$ is supported by the timing of the low, which varies with the position of stress within the name. In the examples in Figure 5, this can be seen in the early position of the low turning point in

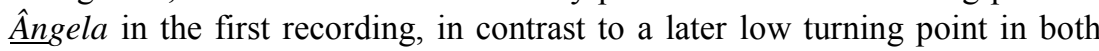
recordings in Eleonor.

In final position a different contour is found, which can be identified as the declarative contour $\mathrm{H}+\mathrm{L} * \mathrm{~L} \%$. A high turning point is seen to precede the last stressed syllable. It is followed by a rapid fall towards a low turning point, which is in the stressed syllable in the second F0-track in Figure 5. The first F0-track of Figure 5 shows an instance with an either incompletely executed or slightly delayed L*.

The first plot in Figure 5 shows a clear sequence of two consecutive $\mathrm{H}$ tones (with a microprosodically distorted plateau between them) that arises in the penultimate/final sequence $\mathrm{L}^{*} \mathrm{H}-\mathrm{H}+\mathrm{L} *$. Plateaus in this position, which may also be rising or falling, are found regularly in our data. In addition, cases like the second plot in Figure 5 are found, which may be said to constitute neither clear evidence for nor clear evidence against the existence of a plateau. 
The results of measurements of these low and high turning points, averaged across the five recordings for each speaker, are shown in Figure 6. (Missing values, in the case of the absence of evidence for a turning point, are: In the penultimate/final sequence $\mathrm{L}^{*} \mathrm{H}-\mathrm{H}+\mathrm{L} *$, two tokens showed no turning point corresponding to $\mathrm{H}$ - and one token showed no evidence of a turning point corresponding to $\mathrm{H}+.14$ out of 30 measurements of the nuclear $\mathrm{L}^{*}$ were skipped in the absence of a low turning point within the stressed syllable.)
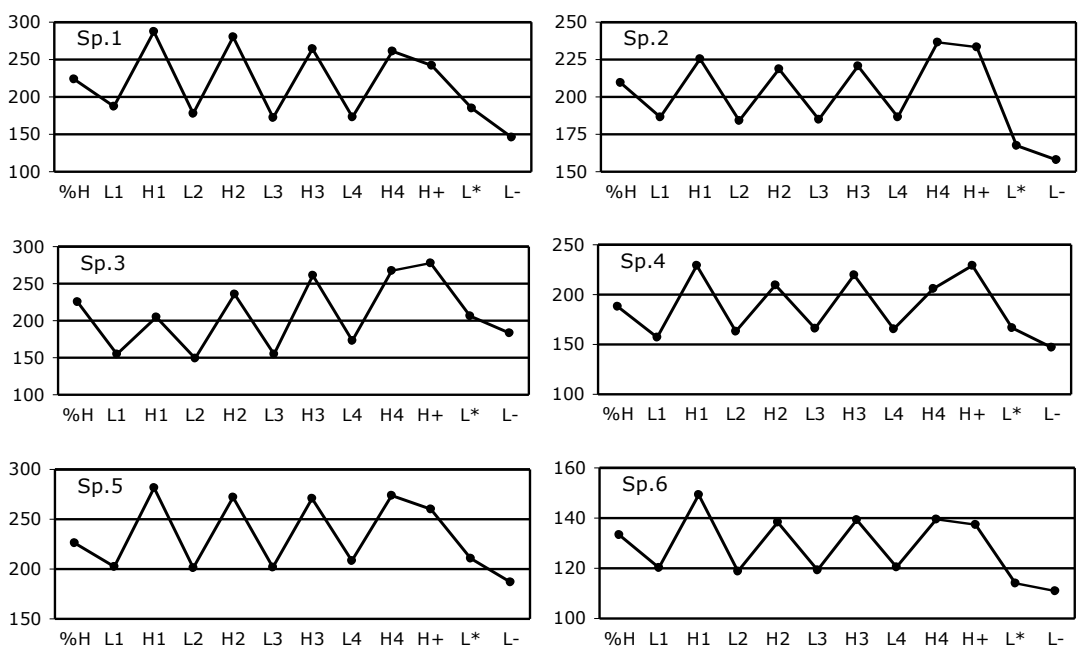

Figure 6. F0-measurements of the peaks and valleys of the lists, separated by speakers.

The relative height of the peaks is not one of successive downstep. The peaks may perhaps be viewed as being on a shared reference-line, which would be rising for speaker 3 and slightly falling for some other speakers. Some speakers seem to raise the initial and/or final peak relative to that line.

There were occasional irregularities in the lists, mostly additional rises on the first syllable of Eleonor, which might be related to secondary stress. This is not reflected in the plots in Figure 6.

In sum, the lists showed final statement contours $\mathrm{H}+\mathrm{L}^{*} \mathrm{~L} \%$ and non-final $\mathrm{L}^{*} \mathrm{H}$ - contours. There was no regular downstep among the peaks of the elements in the lists.

\subsection{Discussion}

The results confirm the analysis of Cagliari $(1981,1982)$ about non-final rises and a final fall in lists. We can refine this in regard to the position of a low turning point on the stressed syllable, and in regard to the existence of a (falling or rising) plateau between the end of the last rise and the beginning of 
the final fall. This plateau occurs in the sequence $\mathrm{L}^{*} \mathrm{H}-\mathrm{H}+\mathrm{L} * \mathrm{~L} \%$ between the end of the penultimate rise and the onset of the final fall.

The finding of $\mathrm{H}-$ also confirms instances of this in Tenani (2002).

More generally, in our recordings we find either $\mathrm{H}+\mathrm{L} * \mathrm{~L} \%$ or $\mathrm{L}^{*} \mathrm{H}-$ in declaratives (final or non-final position), but never both $\mathrm{H}$ tones simultaneously, in what would be $\mathrm{H}+\mathrm{L}^{*} \mathrm{H}-$. We leave open whether this is an accidental or a systematic gap.

In regard to our assignment of pragmatic meanings to the tones, the use of $\mathrm{L}^{*}$ in the non-final $\left(\mathrm{L}^{*}\right)$ and final position $\left(\mathrm{H}+\mathrm{L}^{*}\right)$ of the lists would be a mark of declarative sentences. Among the meaningful elements we defined, this is what we would expect to get in answers to the question in (14). ${ }^{4}$

\section{Intonation in clauses with narrow focus}

In our third experiment we explore the effect of focus on the intonation in BP. Fernandes (2007) presents an analysis of narrow focus on subjects in comparison with no narrow focus in BP in terms of the autosegmentalmetrical approach, and claims that the focused subject can bear either a $\mathrm{H}^{*}+\mathrm{L}$ or a $\mathrm{H}+\mathrm{L}^{*}$ contour, or even $\mathrm{L}^{*}+\mathrm{H}$, like in non-focused statements. Lucente and Barbosa (2008), analyzing data of spontaneous speech, also present an analysis of narrow focus in BP. The authors maintain that typical narrow focus bears the LH contour. According to them, this contour is the most common in BP foci. They also claim that "the LH rising pattern seems necessary in BP for the realization of narrow focus in sentence medial position. However, it presents some variations in agreement with the specific focus function, as occurs in HLH contour. The same happens with HL falling pattern in final sentence position, which presents LHL contour as variation."

Some Romance languages prefer not to mark an early focus by a shift in prominence (López Jiménez 2006 argues this for European Spanish) and/or to mark focus by changing the word order (see Vallduvi 1990 for Catalan, Zubizarreta 1998 for European Spanish, Samek-Lodovici 2005 for Italian).

\footnotetext{
${ }^{4}$ A non-trivial question of detail arises in this connection. Since the lists as a whole would be DPs on a standard syntactic analysis, how can they be marked as 'declarative,' which would seem to be a property of clauses? It is not impossible that the lists in (14) are elliptical answers of which the full clauses are present at LF and marked as declarative there. Another possibility relates to the suggestion of Truckenbrodt (to appear), extending proposals of Bartels (1997). In that suggestion, intonational meanings of English never operate on the output of compositional semantics; rather, they generally operate on salient propositions. It is not obvious that this should carry over to marking of declarative/interrogative in BP, since this is a feature often closely connected to the syntax and compositional semantic interpretation. However, the marking of the lists by $\mathrm{L}^{*}$ may be taken as an indication that $\mathrm{L}^{*}$ marks salient propositions, rather than syntactic sentences as 'declarative' in BP. In the case of our lists, the salient proposition would be the propositional answers to the question in (14).
} 
Other Romance languages seem to shift the main stress to an early focus. The results of Frota (2000) suggest that European Portuguese is such a language. In addition, EP contrasts the default nuclear accent $\mathrm{H}+\mathrm{L}^{*}$ in final position of neutral statements with an $\mathrm{H}^{*}+\mathrm{L}$ focus accent that appears to be obligatorily used in utterances with narrow focus. It appears on the focused element whether this stands in final or non-final position. If it occurs in non-final position, the following F0-range is severely compressed. Frota argues that the $\mathrm{H}+\mathrm{L} *$ final accent is still present in this compressed range on the final word.

Frota (2000) includes a detailed study of the phonetics and phonology of focus realization in European Portuguese. Our current aim for BP is more modest. For one thing, we want to review the effect of narrow focus on the intonation; in addition, we want to have a first statistical assessment of what the main effect of focus is, if any.

\subsection{Method}

The stimuli read by the speakers for experiments one and two also included the three sentences in (1), each tested in four different focus contexts. This is illustrated for (1a) in (15), using English translations of the BP contexts.

(15) Contexts for

Nós manauaras ulularíamos.

'We people from Manaus would scream.'

a. Non-contrastive verb focus

What would you people from Manaus do if Amazonino Mendes won the election?

b. Contrastive verb focus

What would you people from Manaus do if Amazonino Mendes won the election? Would you weep or scream?

c. Non-contrastive subject focus

Who would scream if Amazonino Mendes won the election?

d. Contrastive subject focus

Who would scream if Amazonino Mendes won the election? We people from Manaus or all of Brazil?

With three sentences (1a.-c.) per speaker and condition, we evaluate 18 tokens of each condition from all speakers combined, and a total of 72 tokens for an assessment of the effect of focus.

The recordings were labeled and a tonal contour was postulated for each token. The height of the postulated tones was measured. An additional F0measurement was taken at the beginning of the vowel preceding the stressed vowel of the verb (see below). In addition, the length of the subject and the length of the verb were measured, for an assessment of focus realization by an increase in the relative length of the focused constituent. In the few cases 
where subject and verb are separated by a pause, the pause was not taken into account.

\subsection{Results on narrow focus}

\subsubsection{Pitch accent on final focus}

In all of the 36 tokens with narrow focus on the verb, the verb shows a pitch accent, which in by far the most tokens is the declarative accent $\mathrm{H}+\mathrm{L}^{*}$ preceding L\%. In 34/36 tokens there is clear evidence of a high turning point corresponding to $\mathrm{H}+$ in the syllable preceding the stressed syllable. In these tokens, the presence of this peak rules out an analysis of the pitch accent as $\mathrm{H}^{*}+\mathrm{L}$. A typical contour with verb focus is shown in Figure 7. (We return to the point labeled ' $\mathrm{X}$ ' below.)

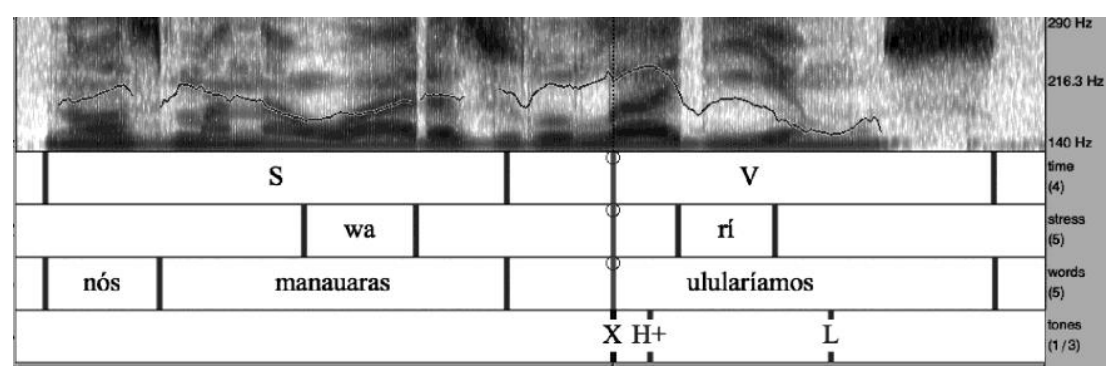

Figure 7. F0-track from recording with narrow focus on the verb.

Figure 7 shows the most noticeable element of this pitch accent, the peak inside of the verb (ulularíamos) that precedes the stressed syllable ( $r i$ ) there, analyzed as $\mathrm{H}+$.

Thus, unlike in EP, in BP the declarative pitch accent does not seem to give way to a focus accent $\mathrm{H}^{*}+\mathrm{L}$ on a final narrow focus.

\subsubsection{Absence/compression of the pitch accent on the verb when the subject is focused}

For four out of the six speakers, there is regularly no evidence of a full pitch accent on the verb when the subject is focused. In many cases there is no evidence of a pitch accent on the verb at all; in other cases, the F0-track is compatible with the presence of a much-compressed pitch accent on the verb. An example is shown in Figure 8. (The point labeled ' $\mathrm{X}$ ' is discussed below.) 


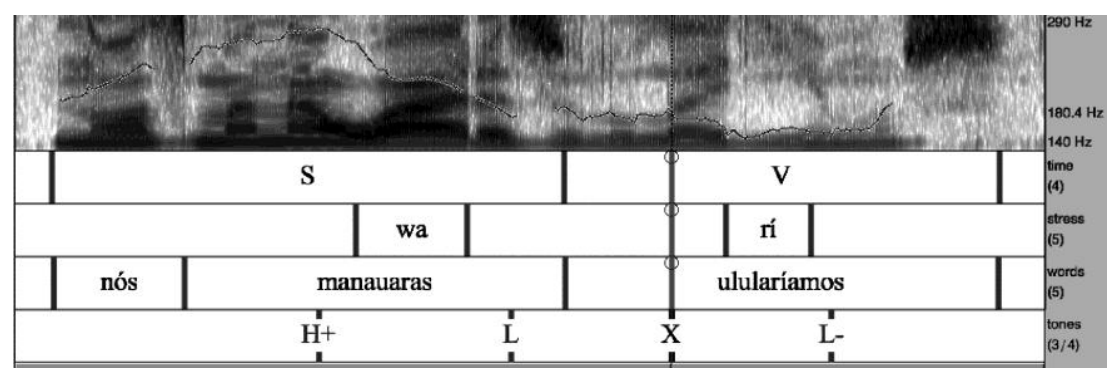

Figure 8. F0-track from recording with narrow focus on the subject.

This absence or strong compression of the final pitch accent on the verb occurs in 22 of the 24 utterances with subject focus of these four speakers. The remaining two speakers (speakers 4 and 5) did not consistently mark an early narrow focus, as will also be seen below. Fernandes (2007) does not mention the absence/compression of the pitch accent on the verb when the subject is focused; her figures illustrating F0-tracks, however, do show such absence/compression.

\subsubsection{Choice of pitch accent on the focused subject}

Among the four speakers who realized the early focus, there is no consistent choice of pitch accent on the noun of the narrowly focused subject in our data. The declarative contour that can be seen on the focused noun in Figure 8 is here only one among a number of patterns we find. With speaker 1 we find instead an $\mathrm{H}^{*}+\mathrm{L}$ pitch accent on the early focus. Sometimes a combination of this with the statement contour is seen, i.e. what could in principle be analyzed as $\mathrm{H}+\mathrm{H}^{*}$. In a few further cases with other speakers, there is an $\mathrm{L}^{*} \mathrm{H}$ - rise on the subject, followed by a fall to the end of the utterance. We add that our stimuli turned out not to be ideally suited for assessing this particular issue, since the pronoun and the noun seem to often both be emphasized with subject focus (Who would scream? WE MaNAUans would scream.).

Nevertheless, the recordings strongly suggest that the EP $\mathrm{H}^{*}+\mathrm{L}$ is not regularly found on an early focus in BP. It does occur, but along with other contours, including the declarative $\mathrm{H}+\mathrm{L}^{*}$. Our results correspond to those of Fernandes (2007) and Lucente and Barbosa (2008).

\subsubsection{Statistical assessment of the focus effect}

We assess the effect of narrow focus statistically, which allows us to also assess effects of additional contrast in our stimuli ((15a) vs. (15b) and (15c) vs. (15d)). We do this in two ways, using F0 and length. We begin with F0. A measurement was taken for all recordings at the beginning of that vowel of the 
verb which precedes the stressed syllable of the verb. The point is labeled ' $\mathrm{X}$ ' in Figures 7 and 8. In the case of focus on the verb, this point is close to the expected location of $\mathrm{H}+$, as can be seen in Figure 7 . In the cases where $\mathrm{H}+\mathrm{L}^{*}$ is not assigned on the verb, this point shows lower F0, since the fall from an earlier $\mathrm{H}$ peak is already partly or entirely executed at this point (see Figure 8).

The effect of focus was assessed statistically by running a series of multiple regressions with mixed factors. Mixed-effects models, or, more simply, "mixed models," incorporate both fixed and random factors (Pinheiro and Bates 2000, Baayen to appear). Generally, a factor is "fixed" if the aim of the experimenter is to explicitly compare the levels of such a factor, while it is "random" if the levels of the variable are regarded as randomly sampled from a larger population. Fixed factors are repeatable; random factors are not, since replicating the experiment would involve selecting other levels of the factor.

In our statistical models, three fixed factors were considered: focus location (2 levels: verb vs. subject), focus kind (non-contrastive vs. contrastive) and type of sentence ((1a) vs. (1b) vs. (1c)).$^{5}$ The six speakers were considered as selected by chance from a larger population of subjects. As a consequence, a random factor "subjects" (with six levels, corresponding to the number of participants in the experiment) was also introduced in the models. The cutoff point for significance was $p M C M C<0.05$.

Figure 9 shows the distribution of the F0-values at the beginning of the vowel across the experimental conditions.

\footnotetext{
${ }^{5}$ Sentence type was regarded as a fixed factor because it is sometimes considered to be more sound to use random factors only when they have five or more levels.
} 


\section{F0 at vowel onset}

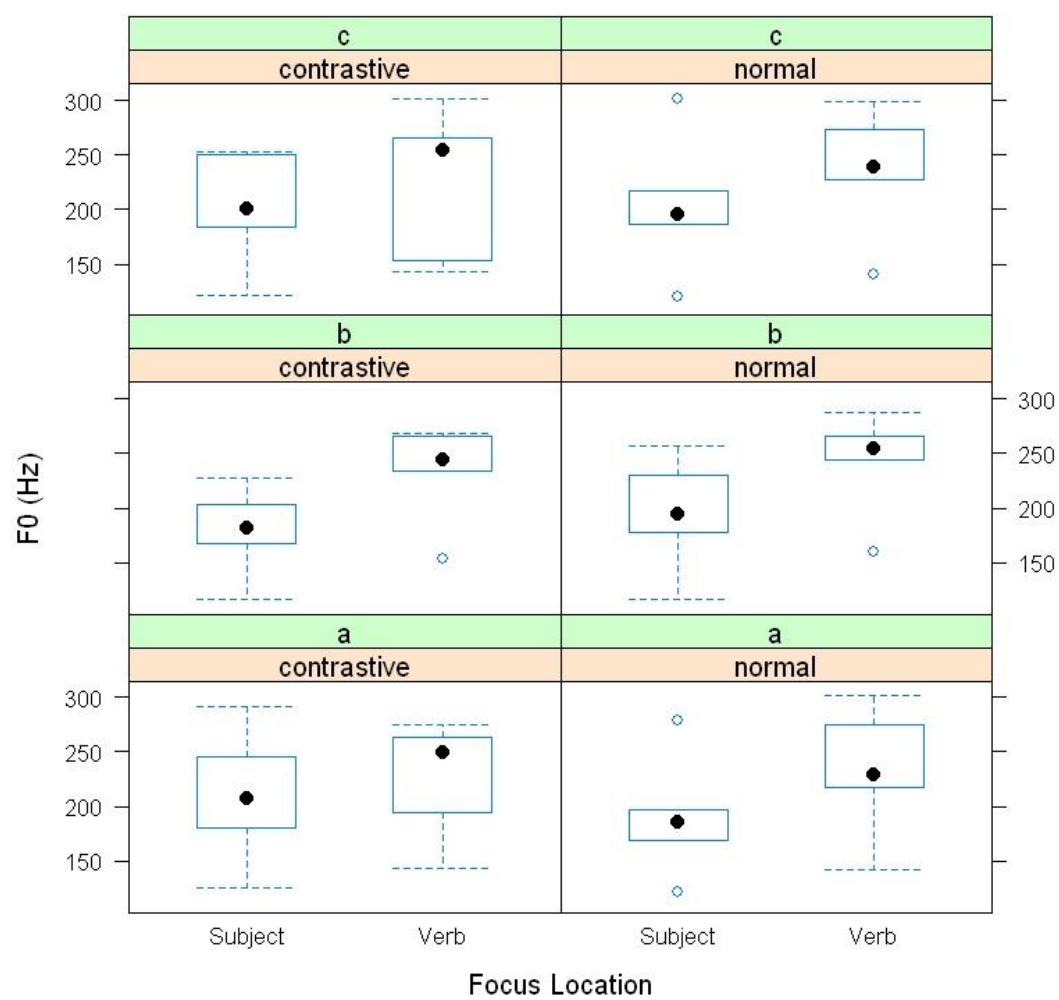

Figure 9. Boxplots of the F0-values extracted at the onset of the vowel preceding the stressed vowel within the verb (y-axis) as a function of focus location (x-axis).

Results are plotted separately for focus kind (columns) and sentence (rows).

As for statistics, we first carried out a linear mixed model in which we evaluated the main effect of the three fixed factors as well as their pairwise interactions on the F0-values extracted from the 72 tokens. However, since the interactions were not significant, they were factored out from the model. The results of the statistical analysis showed a very strong effect of focus location $(t=6.20, p M C M C<0.05)$. F0-values were higher when the focused constituent was a verb (mean value: $232.6 \mathrm{~Hz}$ ) than when it was a subject $(194.7 \mathrm{~Hz})$. On the other hand, neither focus kind nor sentence type were significant $(p M C M C>0.05)$

We further assess the effect of focus statistically in the ratio of the length of the verb to the sum of the length of subject and verb: length_verb/(length_subject + length_verb). The distribution of such a ratio is shown in Figure 10. 


\section{Length ratio}

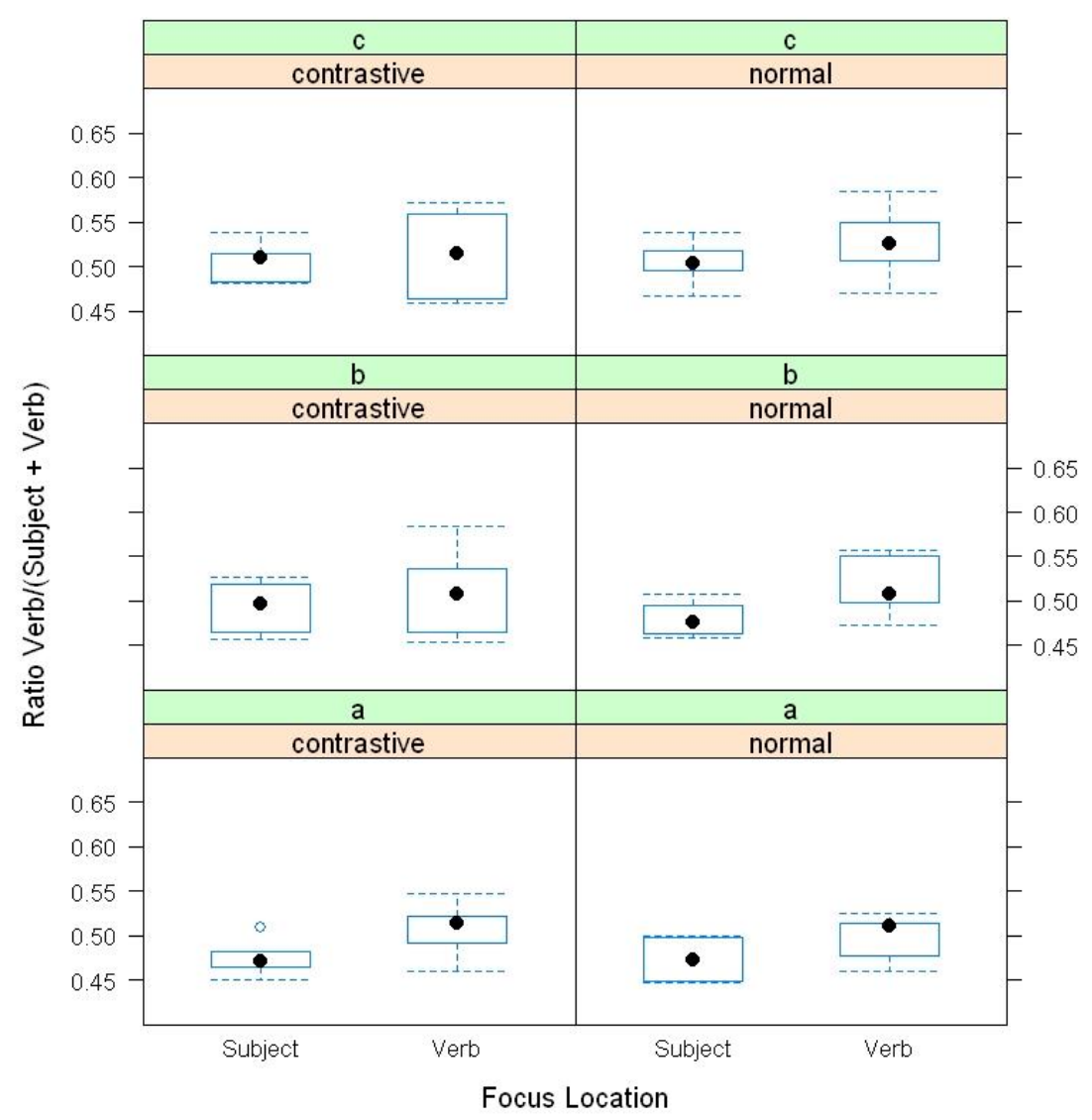

Figure 10. Boxplots of the ratio length_verb/(length_subject + length_verb) (y-axis) as a function of focus location (x-axis). Results are plotted separately for focus kind (columns) and sentence type (rows)

We first ran a mixed model on the 72 ratio-values underlying this plot, in which both the main effect of the experimental factors (focus position, focus kind and sentence type) and their pairwise interactions were taken into account. Similarly to the F0-data, the interactions were not significant and they were thus excluded from the model. A new regression model was run, in which only the effects of the main factors were evaluated. Results showed a significant effect of focus position $(t=4.88, p<0.05)$, confirming that the ratio-values were larger with verb focus (mean ratio value: 0.501 ) than with subject focus $(0.477)$. The model also showed a significant contrast between sentence type "a" and "c" $(t=3.97, p<0.05)$, because the effect of focus is 
clearer for sentence "a" (see also Figure 10). ${ }^{6}$ As above, there was no effect of contrastive vs. non-contrastive focus.

We sum up our results on narrow focus. Our data show clear evidence that narrow focus in non-final position (here: on the subject) is distinguished from narrow focus in final position (here: on the verb) in BP for four of our six speakers. At the same time, narrow focus with and without a contrast in the context was not distinguished. There is no distinction between contrastive and non-contrastive focus in EP either (Frota 2000). On the other hand, since our elicitation of the contrastive condition combined a question-answer sequence with the presence of such contrasting alternatives, we cannot exclude that the contrasts we offered were not realized as contrastive foci by our speakers.) The most consistent effect of focus in non-final position is the absence or compression of the $\mathrm{H}+\mathrm{L}^{*}$ pitch accent in final position. Unlike in $\mathrm{EP}$, the pitch accent is not systematically changed from $\mathrm{H}+\mathrm{L}^{*}$ to $\mathrm{H}^{*}+\mathrm{L}$ under narrow focus. In BP, the pitch accent seems to remain unchanged with final narrow focus. In non-final narrow focus, a variety of possibilities, including $\mathrm{H}+\mathrm{L}^{*}$ and $\mathrm{H}^{*}+\mathrm{L}$, were found.

As mentioned, speakers 4 and 5 did not show clear effects of focus in the inspection of individual F0-tracks. It seems possible to us that these speakers did not 'pick up' on our experimental design, at least not consistently, i.e. that they did not take the focusing context we employed into account when reading the stimuli. However, we cannot exclude that not marking focus intonationally is an option available to and employed by groups of speakers of BP.

\section{Summary and conclusion}

Elements of the intonation of BP as spoken in the Campinas area were investigated. A combined production and perception experiment showed a systematic distinction between statements $\left(\mathrm{H}+\mathrm{L}^{*} \mathrm{~L} \%\right)$, yes/no-questions $\left(\mathrm{L}+\mathrm{H}^{*} \mathrm{~L} \%\right)$ and surprise questions $\left(\mathrm{L}^{*}+\mathrm{H} \mathrm{L} \%\right)$. The pitch accents can be decomposed into declarative $\left(\mathrm{L}^{*}\right)$ vs. interrogative $\left(\mathrm{H}^{*}\right)$ (see also de Moraes $1998)$ with committing $(\mathrm{H}+\mathrm{L})$ vs. non-committing $(\mathrm{L}+\mathrm{H})$ intonation. On this analysis, the surprise question is the BP equivalent to the English declarative question. Initial evidence for this equivalence was given based on the use of these forms. The statement contour $\mathrm{H}+\mathrm{L}^{*} \mathrm{~L} \%$ is shared with EP (Frota 2000, 2002 , to appear). Its phonetic implementation in BP seems to allow for a late or not fully executed $\mathrm{L}^{*}$.

Emphatic statements show raised F0 relative to non-emphatic statements. Surprise questions also show higher F0 than yes/no-questions, in addition to the different alignment (here: different pitch accent).

\footnotetext{
${ }^{6}$ The contrast in the verbs is screaming as opposed to weeping in "a", while it is praying as opposed to crying in "c". It is possible that the intuitively stronger opposition in the first case is responsible for the statistical difference that is observed here.
} 
Continuation is systematically marked by $\mathrm{L}^{*} \mathrm{H}$ - in non-final members of a list.

Narrow focus is regularly marked by four out of our six speakers. In our data, narrow focus on a subject led to the absence, or strong compression, of a pitch accent on the following verb. This seems to be comparable to the strong compression of a nuclear postfocal pitch accent in EP according to Frota (2000). Further, in BP the relative length of a constituent is increased under focus. As for pitch accents, narrow focus in EP is reported to be marked by a $\mathrm{H}^{*}+\mathrm{L}$ focus pitch accent by Frota (2000, 2002, to appear). This does not systematically occur in our BP data, where final narrow focus shows the $\mathrm{H}+\mathrm{L} * \mathrm{~L} \%$ statement contour, and non-final narrow focus shows a variety of contours including the statement contour $\mathrm{H}+\mathrm{L}^{*} \mathrm{~L} \%$ and the $\mathrm{EP}$ focus contour $\mathrm{H}^{*}+\mathrm{L} \mathrm{L} \%$.

\section{Acknowledgments}

We want to thank to Rafael Nonato, João Ricardo Oliveira, Caterina Petrone, Stefan Sudhoff, and Flaviane Fernandes Svartman for help with the experiments, and Plinio Barbosa for helpful comments. This work was supported by the DFG grant TR 747-2 (Truckenbrodt), the FAPESP grant 2004/01569-8 and the CNPq grant 305808/2006-0 (Sândalo), as well as by the CNPq grant 306564/2007-6 (Abaurre). All errors are of course our own.

\section{Appendix}

A. Nuclear contours

Assertions

1. O que aconteceria se Amazonino Mendes ganhasse a eleição?

'What would happen if Amazonino Mendes won the election?'

Nós manauaras ulularíamos.

'We people from Manaus would scream.'

2. O que aconteceria se Chomsky escrevesse um outro livro?

'What would happen if Chomsky wrote another book?'

Nós alunos leríamos.

'We students would read it.'

3. O que aconteceria se Maria adoecesse seriamente?

'What would happen if Mary got seriously ill?'

Nós meninos oraríamos.

'We boys would pray.' 
Yes/no-questions

4. O que você acha que aconteceria se Amazonino Mendes ganhasse a eleição? Nós manauaras ulularíamos?

'What do you think would happen if Amazonino Mendes won the election? Would we people from Manaus scream?'

5. O que você acha que aconteceria se Chomsky escrevesse um outro livro? Nós alunos leríamos?

'What do you think would happen if Chomsky wrote another book? Would we students read it?'

6. O que você acha que aconteceria se Maria adoecesse seriamente?

Nós meninos oraríamos?

'What do you think would happen if Maria got seriously ill? Would we boys pray?'

Surprise questions

7. Eu acho que vocês manauaras ululariam se Amazonino Mendes ganhasse a eleição.

'I believe that you people from Manaus would scream if Amazonino Mendes won the election.'

Nós manauaras ulularíamos!? De jeito nenhum.

'We people from Manaus would scream? No way.'

8. Eu acho que vocês alunos leriam se Chomsky escrevesse um outro livro.

'I think you students would read it if Chomsky wrote another book.'

Nós alunos leríamos!? De jeito nenhum.

'We students would read it!? No way.'

9. Eu acho que vocês meninos orariam se Maria adoecesse seriamente.

'I think you boys would pray if Maria got seriously ill.'

Nós meninos oraríamos!? De jeito nenhum.

'We boys would pray!? No way.'

Continuation assertions

10. O que você acha que aconteceria se Amazonino Mendes ganhasse a eleição?

'What do you think would happen if Amazonino Mendes won the election?'

Nós manauaras ulularíamos, mas nada iria mudar.

'We people from Manaus would scream, but nothing would change.'

11. O que você acha que aconteceria se Chomsky escrevesse um outro livro? 'What do you think would happen if Chomsky wrote another book?' Nós alunos leríamos, mas talvez tivéssemos muita dificuldade.

'We students would read it, but maybe we would find it very difficult.' 
12. O que você acha que aconteceria se Maria adoecesse seriamente? 'What do you think would happen if Maria got seriously ill?' Nós meninos oraríamos, mas ela deveria consultar um médico. 'We boys would pray, but she should see a doctor.'

Emphatic assertions

13. Eu acho que vocês não ululariam se Amazonino Mendes ganhasse a eleição.

'I don't think that you would scream if Amazonino Mendes won the election.'

Mas nós manauaras ulularíamos!

'But we people from Manaus would scream!'

14. Eu acho que vocês não leriam se Chomsky escrevesse um outro livro.

'I don't think you would read it if Chomsky wrote another book.'

Mas nós alunos leríamos!

'But we students would read it!'

15. Eu acho que vocês não orariam se Maria adoecesse seriamente.

'I don't think you would pray if Maria got seriously ill.'

Mas nós meninos oraríamos!

'But we boys would pray.'

B. Narrow focus

Narrow focus on verb

16. O que vocês manauaras fariam se Amazonino Mendes ganhasse a eleição?

'What would you people from Manaus do if Amazonino Mendes won the election?'

Nós manauaras ulularíamos.

'We people from Manaus would scream.'

17. O que vocês alunos fariam se Chomsky escrevesse um novo livro?

'What would you students do if Chomsky wrote a new book?'

Nós alunos leríamos.

'We students would read it.'

18. O que vocês meninos fariam se Maria adoecesse seriamente?

'What would you boys do if Mary got seriously ill?'

Nós meninos oraríamos.

'We boys would pray.'

Narrow focus on subject

19. Quem ulularia se Amazonino Mendes ganhasse a eleição?

'Who would scream if Amazonino Mendes won the election?'

Nós manauaras ulularíamos.

'We people from Manaus would scream.' 
20. Quem leria o novo livro do Chomsky?

'Who would read Chomsky's new book?'

Nós alunos leríamos.

'We students would read it.'

21. Quem oraria se Maria adoecesse seriamente?

'Who would pray if Mary got seriously ill?'

Nós meninos oraríamos.

'We boys would pray.'

Contrastive focus on verb

22. O que vocês manauaras fariam se Amazonino Mendes ganhasse a eleição? Vocês chorariam ou ululariam?

'What would you people from Manaus do if Amazonino Mendes won the election? Would you weep or scream?'

Nós manauaras ulularíamos.

'We people from Manaus would scream.'

23. O que vocês alunos fariam se Chomsky escrevesse um novo livro? Vocês leriam ou ignorariam?

'What would you students do if Chomsky wrote a new book? Would you read it or ignore it?'

Nós alunos leríamos.

'We students would read it.'

24. O que vocês meninos fariam se Maria adoecesse seriamente?

Vocês orariam ou chorariam?

'What would you boys do if Mary got seriously ill? Would you pray or cry?'

Nós meninos oraríamos.

'We boys would pray.'

Contrastive focus on subject

25. Quem ulularia se Amazonino Mendes ganhasse a eleição? Vocês manauaras ou todos os brasileiros?

'Who would scream if Amazonino Mendes won the election? You people from Manaus or all of Brazil?'

Nós manauaras ulularíamos.

'We people from Manaus would scream.'

26. Quem leria o novo livro do Chomsky? Vocês alunos ou nós professores?

'Who would read Chomsky's new book? You students or we teachers?'

Nós alunos leríamos.

'We students would read it.' 
27. Quem oraria se Maria adoecesse seriamente? Vocês meninos ou a mãe dela?

'Who would pray if Mary got seriously ill? You boys or her mother?' Nós meninos oraríamos.

'We boys would pray.'

\section{Lists}

Quem você viu na festa?

'Who did you see at the party?'

28. A Manuela, o Manolo, a Laura, a Ângela e a Eleonor.

29. O Manolo, a Laura, a Ângela, a Eleonor e a Manuela.

30. A Laura, a Ângela, a Eleonor, a Manuela e o Manolo.

31. A Ângela, a Eleonor, a Manuela, o Manolo e a Laura.

32. A Eleonor, a Manuela, o Manolo, a Laura e a Ângela.

\section{References}

Baayen, H. (to appear) Analyzing linguistic data: A practical introduction to statistics. Cambridge: Cambridge University Press.

Bartels, C. (1997) Towards a compositional interpretation of English statement and question intonation. Doctoral thesis, University of Massachusetts, Amherst.

Beckman, M. E. \& Pierrehumbert, J. B. (1986) Intonational structure in Japanese and English, Phonology Yearbook, 3, 255-309.

Bolinger, D. (1986) Intonation and its parts: Melody in spoken English. Palo Alto: Stanford University Press.

Cagliari, L. C. (1981) Elementos de fonética do Português Brasileiro. Ms., Universidade Estadual de Campinas.

Cagliari, L. C. (1982) Aspectos acústicos da entoação do Português Brasileiro, Linguagem oral, linguagem escrita. Série Estudos 8. Faculdades Integradas de Uberaba, 45-59.

Cruz-Ferreira, M. (1998) Intonation in European Portuguese. In Intonation systems. A survey of twenty languages, (D. Hirst \& A. Di Cristo, editors), pp. 167-178. Cambridge: Cambridge University Press.

de Moraes, J. A. (1984) Recherches sur l'Intonation modale du Portugais Brésilien Parlé à Rio de Janeiro. Doctoral thesis, University of Paris III.

de Moraes, J. A. (1998) Intonation in Brasilian Portuguese. In Intonation systems. A survey of twenty languages, (D. Hirst \& A. Di Cristo, editors), pp. 179-194. Cambridge: Cambridge University Press.

Fernandes, F. R. (2007) Tonal association in neutral and subject-narrow-focus sentences in Brazilian Portuguese: A comparison with European Portuguese, Journal of Portuguese Linguistics, 5/6, 91-115.

Fógnagy, I. (1981) Fonction prédictive de l'intonation. In Problèmes de Prosodie, II, Expérimentations, modèles et fonctions, (P. Léon \& M. Rossi, editors), pp. 113120. Ottawa: Didier. 
Frota, S. (2000) Prosody and focus in European Portuguese. New York: Garland.

Frota, S. (2002) Nuclear falls and rises in European Portuguese: A phonological analysis of declarative and question intonation. Probus 14, 113-146.

Frota, S. (to appear) The intonational phonology of European Portuguese. In Prosodic Typology II, (Sun-Ah Jun, ed.). Oxford: Oxford University Press.

Frota, S. \& Vigário, M. (2000) Aspectos de Prosódia Comparada: Ritmo e Entoação no PE e no PB, In Actas do XV Encontro Nacional da Associação Portuguesa de Linguística (R. Castro \& P. Barbosa, editors), pp. 533-555, Braga: APL.

Gebara, E. S. (1976) Alguns aspectos da intonação no Português. Master's thesis, Universidade Estadual de Campinas.

Grabe, E. (1998) Comparative intonational phonology: English and German. Doctoral thesis, Universiteit Nijmegen.

Gunlogson, C. (2001) True to form: rising and falling declaratives as questions in English. Doctoral thesis, University of California.

Gussenhoven, C. (2004) The phonology of tone and intonation. Cambridge: Cambridge University Press.

Halliday, M. A. K. (1967) Intonation and grammar in British English. The Hague: Mouton.

Hirschberg, J. \& Ward, G. (1992) The influence of pitch range, duration, amplitude and spectral features on the interpretation of the rise-fall-rise intonation contour in English, Journal of Phonetics, 20, 241-251.

Ladd, D. R. (1996) Intonational phonology. Cambridge: Cambridge University Press.

Laniran, Y. (1992) Intonation in tone languages: the phonetic implementation of tones in Yorùbá. Doctoral thesis, Cornell University.

Liberman, M. \& Pierrehumbert, J. B. (1984) Intonational invariance under changes in pitch range and length. In Language, sound, structure: Studies in phonology presented to Morris Halle by his teacher and students, (M. Aronoff \& R. T. Oehrle, editors), pp. 157-233. Cambridge, MA: MIT Press.

López Jiménez, B. (2006) Aspekte der spanischen Prosodie anhand von Fragesätzen. Master's thesis, Tübingen University.

Lucente, L. \& Barbosa, P. A. (2008) Narrow focus in Brazilian Portuguese: Spatial and temporal constraints. In Proceedings of the Fourth Conference on Speech Prosody, 2008. v. 01, 281-284.

Massini-Cagliari, G. \& Cagliari, L. C. (2001) Fonética. In Introdução à lingüística, (F. Mussalim \& A. C. Bentes, editors), pp. 105-142. São Paulo: Cortez.

Pierrehumbert, J. B. (1980) The phonology and phonetics of English intonation. Doctoral thesis, Massachusetts Institute of Technology.

Pierrehumbert, J. \& Hirschberg, J. (1990) The meaning of intonational contours in the interpretation of discourse. In Intentions in communication, (P. R. Cohen, J. Morgan \& M. E. Pollack, editors), pp. 271-311. Cambridge: MIT Press.

Pinheiro, J. C. \& Bates, D. M. (2000) Mixed-effects models in S and S-plus. New York: Springer.

Prieto, P., Shih, C.-L. \& Nibert, H. (1996) Pitch down trend in Spanish, Journal of Phonetics, 24, 445-473.

Samek-Lodovici, V. (2005) Prosody syntax interaction in the expression of focus, Natural Language \& Linguistic Theory, 23, 687-755. 
Tenani, L. E. (2002) Domínios prosódicos no português do Brasil: implicações para a prosódia e para a aplicação de processos fonológicos. Doctoral thesis, Universidade Estadual de Campinas.

Truckenbrodt, H. (2004) Final lowering in non-final position, Journal of Phonetics, 32, 313-348.

Truckenbrodt, H. (2007) Upstep of edge tones and of nuclear accents. In Tones and tunes. Volume 2: Experimental studies in word and sentence prosody, (C. Gussenhoven \& T. Riad, editors), pp. 349-386. Berlin: Mouton.

Truckenbrodt, H. (to appear) Semantics of intonation. In Handbook of semantics, (C. Maienborn, K. v. Heusinger \& P. Portner, editors). Berlin: Mouton.

Vallduvi, E. (1990) The informational component. Doctoral thesis, University of Pennsylvania.

Zubizarreta, M. L. (1998) Prosody, focus, and word order. Cambridge, MA: MIT Press.

\author{
Hubert Truckenbrodt \\ ZAS \\ Schützenstr. 18 \\ 10117 Berlin \\ Germany \\ truckenbrodt@zas.gwz-berlin.de
}

\author{
Filomena Sandalo \\ Department of Linguistics \\ IEL/UNICAMP \\ Campinas- SP 13083-970 \\ Brazil \\ fsandalo@gmail.com
}

\author{
Bernadete Abaurre \\ Department of Linguistics \\ IEL/UNICAMP \\ Campinas- SP 13083-970 \\ Brazil \\ bernadete.abaurre@gmail.com
}

